\title{
Measurement of the Volatility and Glass Transition Temperatures of Glasses Produced During the DWPF Startup Test Program (U)
}

by

J. C. Marra

Westinghouse Savannah River Company

Savannah River Site

Aiken, South Carolina 29808

J. R. Harbour

This paper was prepared in connection with work done under the above contract number with the U.S.

Department of Energy. By acceptance of this paper, the publisher and/or recipient acknowledges the U.S. Government's right to retain a nonexclusive, royalty-free license in and to any copyright covering this paper, along with the right to reproduce and to authorize others to reproduce all or part of the copyrighted paper. 


\section{DISCLAMIER}

Portions of this document may be illegible in electronic image products. Imoges are produced from the best available original document. 


\section{DISCLAIMER}

This report was prepared as an account of work sponsored by an agency of the United States Government. Neither the United States Government nor any agency thereof, nor any of their employees, makes any warranty, express or implied, or assumes any legal liability or responsibility for the accuracy, completeness, or usefulness of any information, apparatus, product, or process disclosed, or represents that its use would not infringe privately owned rights. Reference herein to any specific commercial product, process, or service by trade name, trademark, manufacturer, or otherwise does not necessarily constitute or imply its endorsement, recommendation, or favoring by the United States Government or any agency thereof. The views and opinions of authors expressed herein do not necessarily state or reflect those of the United States Government or any agency thereof.

This report has been reproduced directly from the best available copy.

Available to DOE and DOE contractors from the Office of Scientific and Technical Information, P.O. Box 62, Oak Ridge, TN 37831; prices available from (615) 576-8401.

Available to the public from the National Technical Information Service, U.S. Department of Commerce, 5285 Port Royal Road, Springfield, VA 22161. 
WSRC-TR-95-0428

Measurement of the Volatility and Glass Transition Temperatures of Glasses Produced During the DWPF Startup Test Program - (U)

James C. Nara and John R. Harbour

Westinghouse Savannah River Company

Savannah River Technology Center

Aiken, SC 29802
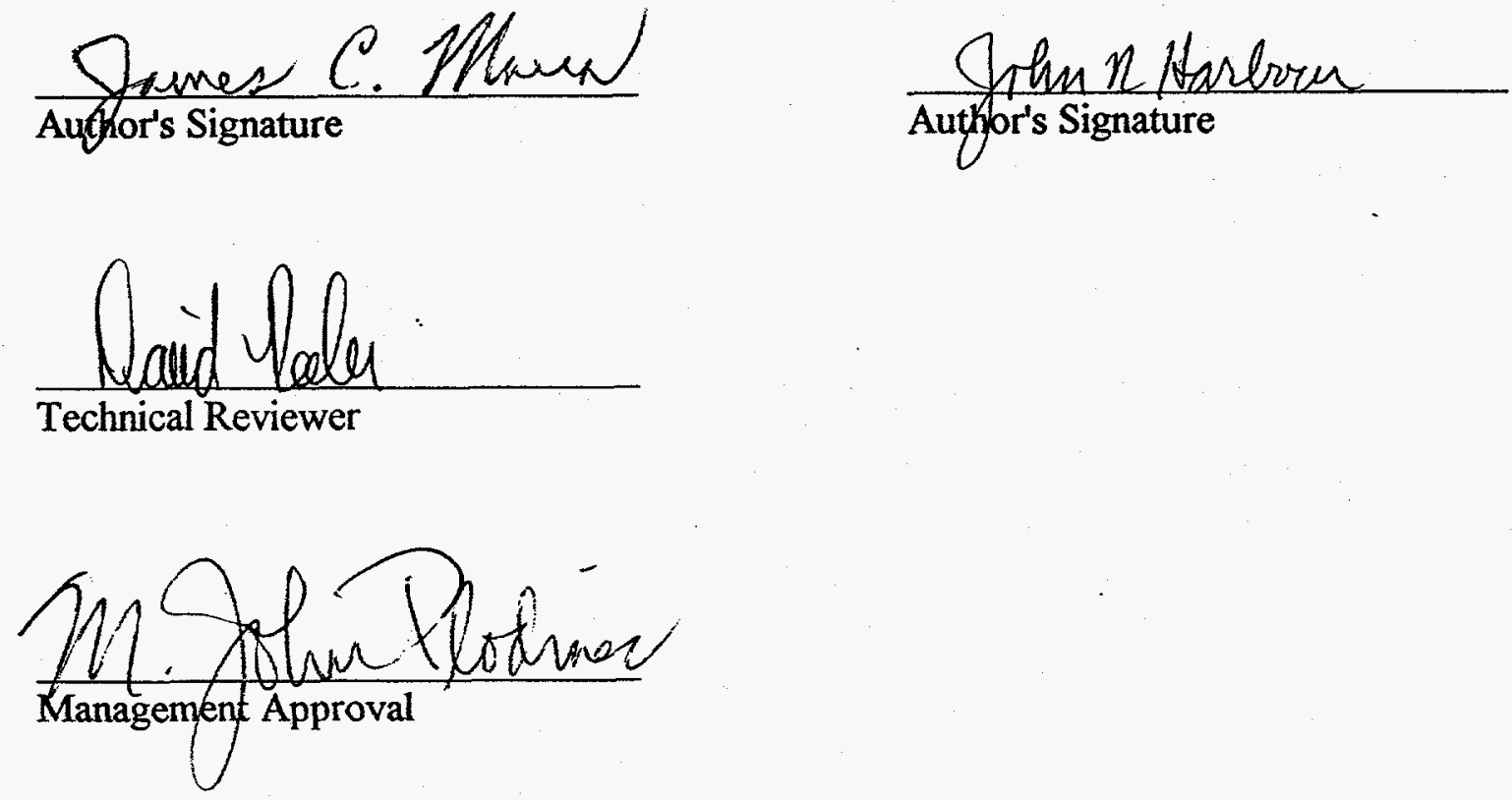
WESTINGHOUSE SAVANNAH RIVER CO. SAVANNAH RIVER TECHNOLOGY CENTER

WSRC-TR-95-0428

Rev. 0

Keywords: Thermogravimetric Analysis (TGA), Differential Scanning Calorimetry (DSC), High-level waste glass, DWPF Qualification runs

Retention: Permanent

October 18, 1995

Measurement of the Volatility and Glass Transition Temperatures of Glasses Produced During the DWPF Startup Test Program - (U)

James C. Marra and John R. Harbour

Westinghouse Savannah River Company

Savannah River Technology Center

Aiken, South Carolina

\section{Summary}

Glass samples from five melter campaigns, run as part of the Defense Waste Processing Facility (DWPF) Startup Test Program, were analyzed to determine glass transition temperatures and to examine for volatilization (by weight loss). Glass transition temperatures $\left(\mathrm{T}_{\mathrm{g}}\right)$ for the glasses, determined by differential scanning calorimetry (DSC), ranged between $445^{\circ} \mathrm{C}$ and $474^{\circ} \mathrm{C}$. Thermogravimetric analysis (TGA) scans showed that no overall weight loss occurred in any of the glass samples when heated to $500^{\circ} \mathrm{C}$. Therefore, no volatility will occur in the final glass product when heated up to $500^{\circ} \mathrm{C}$.

\section{Introduction}

The Defense Waste Processing Facility (DWPF) will immobilize high-level radioactive waste currently stored in underground tanks at the Savannah River Site by incorporating the waste into a glass matrix. The molten waste glass will be poured into stainless steel canisters which will be welded shut to produce the final waste form. The Department of Energy (DOE) has issued the Waste Acceptance Product Specifications (WAPS) which must be satisfied prior to shipment of the waste forms to a final Federal Repository [1]. One of these specifications requires that any volatiles produced as a 
result of accidentally heating the waste glass to the glass transition temperature be identified. The rationale for identifying volatile species is to ensure compatibility with the stainless steel and to ensure the species are not "foreign materials" as defined in the WAPS.

The DWPF Startup Test Program produced 71 canistered waste forms during five melter campaigns. As part of efforts to demonstrate compliance with the WAPS, a test program was performed to determine glass transition temperatures and to identify any volatility in samples from the Startup Test campaigns.

Previous work demonstrated that no detectable volatiles are produced when simulated high-level waste glass is heated to the region of the glass transition temperature $[2,3]$. In fact, all of the glass samples examined exhibited a net weight gain upon heating. The weight gain was found to be caused by oxygen uptake in the glass resulting in the oxidation of $\mathrm{FeO}$ to $\mathrm{Fe}_{2} \mathrm{O}_{3}$. The weight increase was found to be glass particle size dependent since -200 mesh glass powder samples exhibited weight gains while glass "chunks" showed no detectable weight gain upon heating [3].

\section{Experimental}

Glass Samples

Glass samples for analysis were obtained through the Glass Sampling Program performed by SRTC [4]. To ensure the glass represented steady-state melter processing conditions samples from the last three canisters for each campaign were analyzed. Information regarding canister campaign, canister identification and sample identification for the glasses examined is listed in Table I. For TGA experiments, glasses were ground and sieved to obtain -200 mesh powder for analysis. .

Glass Transition Temperature Determination

Differential scanning calorimetry (DSC) measures changes in heat flow within a material relative to a standard upon heating at a controlled rate. DSC is routinely used to detect endothermic and exothermic behavior in materials when heated. Glass transition temperature $\left(\mathrm{T}_{\mathrm{g}}\right)$ can be determined from analysis of an endothermic peak in a DSC scan [5]. The convention for DSC analysis is to define the onset of a reaction as the intersection of tangent lines to the baseline of the scan and the linear portion of the endothermic peak (Figure 1) [3,5]. The glass transition temperature for each sample was determined in this manner. 
Table I. Glass Sampling Data

\section{Melter Campaign}

FA-13

WP-14

WP-15

WP-16
Canister Identification

S00004

S00146

S00114

S00009

S00162

S00155

S00179

S00181

S00407

S00194

S00184

S00408
Sample Identification

11

36

46

86

89

104

214

222

235

313

320

337

388

389

391

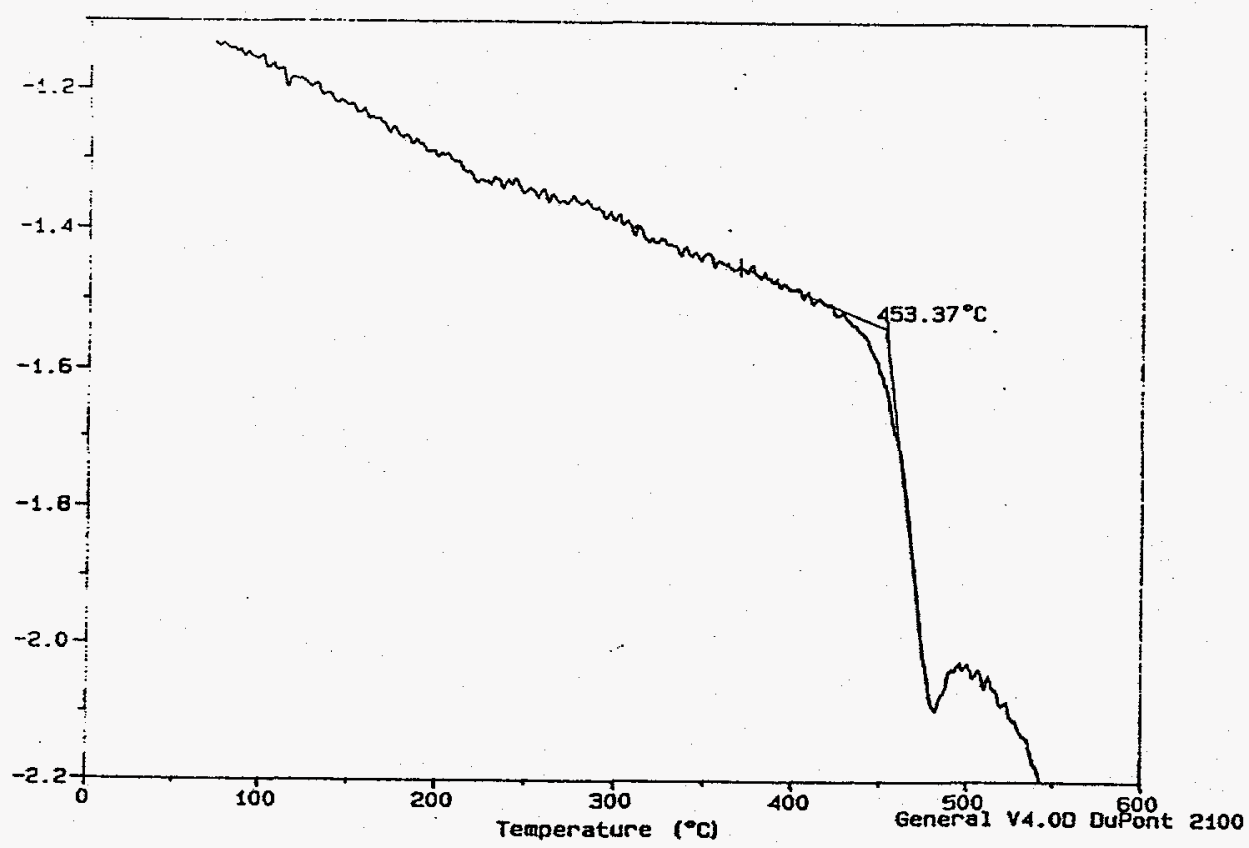

Figure 1. Methodology for identifying $T_{g}$ from a DSC scan. 
Differential scanning calorimetry experiments were performed using a TA Instruments $910 \mathrm{DSC}$ and a 2100 thermal analyzer. Approximately $5 \mathrm{mg}$ of glass was placed in a crimped aluminum pan and heated vs. an empty aluminum reference pan. Samples were heated at $10^{\circ} \mathrm{C} / \mathrm{min}$ to $550^{\circ} \mathrm{C}$ from room temperature, held for one minute and then cooled at $10^{\circ} \mathrm{C} / \mathrm{min}$ to room temperature. A repeat scan was performed on each sample as a verification tool and to examine for changes in $T_{g}$ consistent with those identified in previous studies [3]. The melting point of zinc $\left(419.6^{\circ} \mathrm{C}\right)$ was used before and after experimentation as a reference standard. Values within $1 \%$ of the melting point were considered acceptable for certification of calibration. Calibration runs were all within this tolerance with a maximum deviation of $0.83 \%$ from the zinc melting point.

\section{Glass Volatility}

Thermogravimetric analysis (TGA) is a technique to measure weight changes in a sample as a function of temperature. Thermogravimetric analysis was utilized in this study to identify volatility in the glasses during heating to temperatures up to the glass transition temperature. Testing was performed using a TA Instruments 951 TGA and 2100 Thermal Analyzer. The sensitivity of the instrument was approximately $10 \mu \mathrm{g}$. For each sample, approximately $10-25 \mathrm{mg}$ of -200 mesh glass powder was heated in a platinum sample pan using the following thermal profile: heat from room temperature to $500^{\circ} \mathrm{C}$ at $10^{\circ} \mathrm{C} / \mathrm{min}$; cool to $100^{\circ} \mathrm{C}$ at the same rate. A TGA scan of calcium oxalate monohydrate was used at the beginning and the end of testing to provide an indication of proper temperature calibration [2].

\section{Results and Discussion}

Glass Transition Temperature

Glass transition temperatures for the 15 glasses examined are listed in Table II. The $T_{g}$ values ranged from $445.4^{\circ} \mathrm{C}$ to $473.5^{\circ} \mathrm{C}$. The highest glass transition temperatures were observed in the FA-13 campaign while essentially equivalent lower values were observed in the final three campaigns (WP-15, WP-16, and WP-17). Glass transition temperature values were typically lower following the second heating. This behavior may be explained by the fact that glass transition temperatures in amorphous materials is strongly affected by the glasses' thermal "history" [6]. This behavior may also have been caused by "interferences" associated with the analytical technique [5]. The presence of impurities in the sample, reactions of the sample with air, and inhomogeneities from sample to sample have all been observed to alter $T_{g}$ experimental results. It is interesting to note that in a previous study $T_{g}$ values were observed to increase during the second heating [3]. This may be due to significant variation in time 
from the initial glass melting to when samples were analyzed using DSC. In the previous study [3], the glass samples were examined by DSC several years after initial melting and stress relief may have occurred in the glasses over time.

Appendix A contains the DSC scans for the 15 glasses.

Table II. Glass Transition Temperature $\left(\mathrm{T}_{\mathrm{g}}\right)$ Results $\left({ }^{\circ} \mathrm{C}\right)$

\begin{tabular}{ccc} 
Sample Identification & $\mathbf{T}_{\mathrm{g}}$ First Heating & $\mathrm{T}_{\mathrm{g}}$ Second Heating \\
\hline 11 & 467.6 & 468.9 \\
36 & 473.5 & 470.4 \\
46 & 468.1 & 466.1 \\
& & \\
86 & 464.2 & 458.1 \\
89 & 466.2 & 459.1 \\
104 & 465.0 & 462.2 \\
& & \\
214 & 453.1 & 448.6 \\
222 & 451.5 & 448.1 \\
235 & 450.6 & 444.0 \\
& & \\
313 & 451.3 & 446.1 \\
320 & 452.6 & 445.4 \\
337 & 450.2 & 445.0 \\
388 & & \\
389 & 452.8 & 445.1 \\
391 & 451.1 & 440.8 \\
& 445.4 & 446.7
\end{tabular}

\section{Glass Volatility}

No volatility was observed in any of the glass samples within the accuracy and sensitivity of the thermogravimetric analyzer. There was some baseline drift (implying a weight gain) observed during the runs. Therefore, net weight changes were determined by analyzing differences between the heat-up and cool-down scans. A sample of SGM 7-8 glass was run as a comparison to these and past experimental results $[2,3]$. In the FA-13 tests, a slight weight gain (not exceeding 0.3 wt \%) 
in the glasses was observed. This slight weight gain may be attributable to oxygen uptake in samples resulting in the conversion of $\mathrm{FeO}$ to $\mathrm{Fe}_{2} \mathrm{O}_{3}$ in the glasses [2]. The SGM 7-8 glass, representing a reduced glass $\left(\mathrm{Fe}^{2+} /(\Sigma \mathrm{Fe})=0.63\right)$, gained approximately $0.5 \mathrm{wt} \%$ on heating to $500^{\circ} \mathrm{C}$. This behavior was consistent with previous observations for this glass [2,3]. The remainder of the glass samples (from campaigns WP-14 to WP-17) showed essentially no weight change upon heating. In these cases, the heat-up and cool-down baseline scans were essentially coincident and any deviations were typically less than $0.1 \mathrm{wt} \%$ (approaching the sensitivity of the instrument). The DWPF startup test program glasses were analytically determined to be highly oxidized $\left(\mathrm{Fe}^{2+} /(\Sigma \mathrm{Fe}) \approx 0.01\right)$. This thermal behavior is typical of oxidized glasses [3].

The TGA scans for these glasses are contained in Appendix B. Since the area of measurement interest was near the sensitivity of the instrument, some slight deviations associated with room vibrations and system "noise" are evident in the scans.

\section{Conclusions}

The following conclusions were drawn from thermal analysis testing of 15 glass samples from the five campaigns of the DWPF Startup Test Program:

- Glass transition temperatures determined by Differential Scanning Calorimetry (DSC) ranged between 445 to $474^{\circ} \mathrm{C}$. A slight decrease in $T_{g}$ was evident following repeat heating of the glasses likely due to differences in the thermal history of the glass.

- Thermogravimetric analysis (TGA) showed no weight loss occurred in the tested glasses within the sensitivity of the instrument. Therefore, no volatility will occur in the final glass product when heated to temperatures up to $500^{\circ} \mathrm{C}$.

\section{References}

de 1. Office of Environmental Restoration and Waste Management, "Waste Acceptance Product Specifications for Vitrified High-Level Waste Forms," USDOE Document EM-WAPS, Germantown, MD, 1993.

Qk 2. J. R. Harbour, "Volatility of Simulated High-Level Nuclear Waste Glasses by Thermogravimetric Analysis," J. Am. Ceram. Soc., 75, p. 507, 1992. 
E. W. Holtzscheiter

Page 7 of 7

WSRC-TR-95-0428

de. 3. J. R. Harbour, J. C. Mara and N. E. Bibles, "The Effect of Gamma Irradiation on the Volatility and Redox State of Simulated DWPF High-Level Nuclear Waste Glasses," High Level Radioactive Waste Management - Proceedings of the Fourth Annual International Conference, Las Vegas, NV, p. 1735, 1993.

of 4. GTOP-3-059, "Glass Sampling of DWPF Canisters", Rev. 1, Category 1., Issued 9/6/94, Glass Technology Procedures Manual, L13-1, Rev. 39, June 1, 1995.

6. 5. ASTM E 1356-91, "Standard Test Method for Glass Transition Temperatures by Differential Scanning Calorimetry or Differential Thermal Analysis", 1994 Annual Book of ASTM Standards, Vol. 14.02, p. 810.

Ste 6. W. D. Kingery, H. K. Bowen and D. R. Uhlmann, Introduction to Ceramics, John Wiley and Sons, New York, p. 92, 1976. 
E. W. Holtzscheiter

WSRC-TR-95-0428

APPENDIX A: Differential Scanning Calorimetry (DSC) Scans 


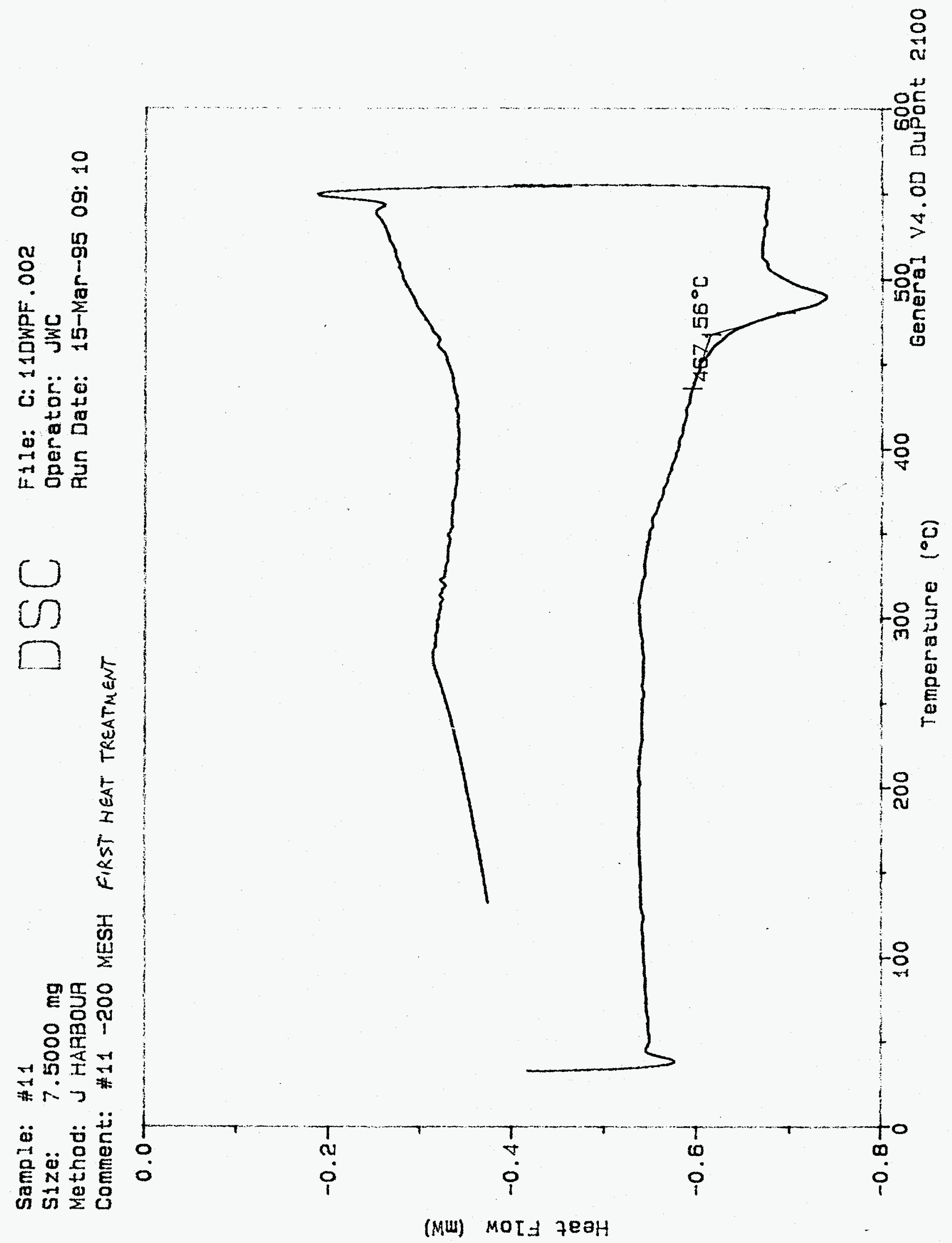




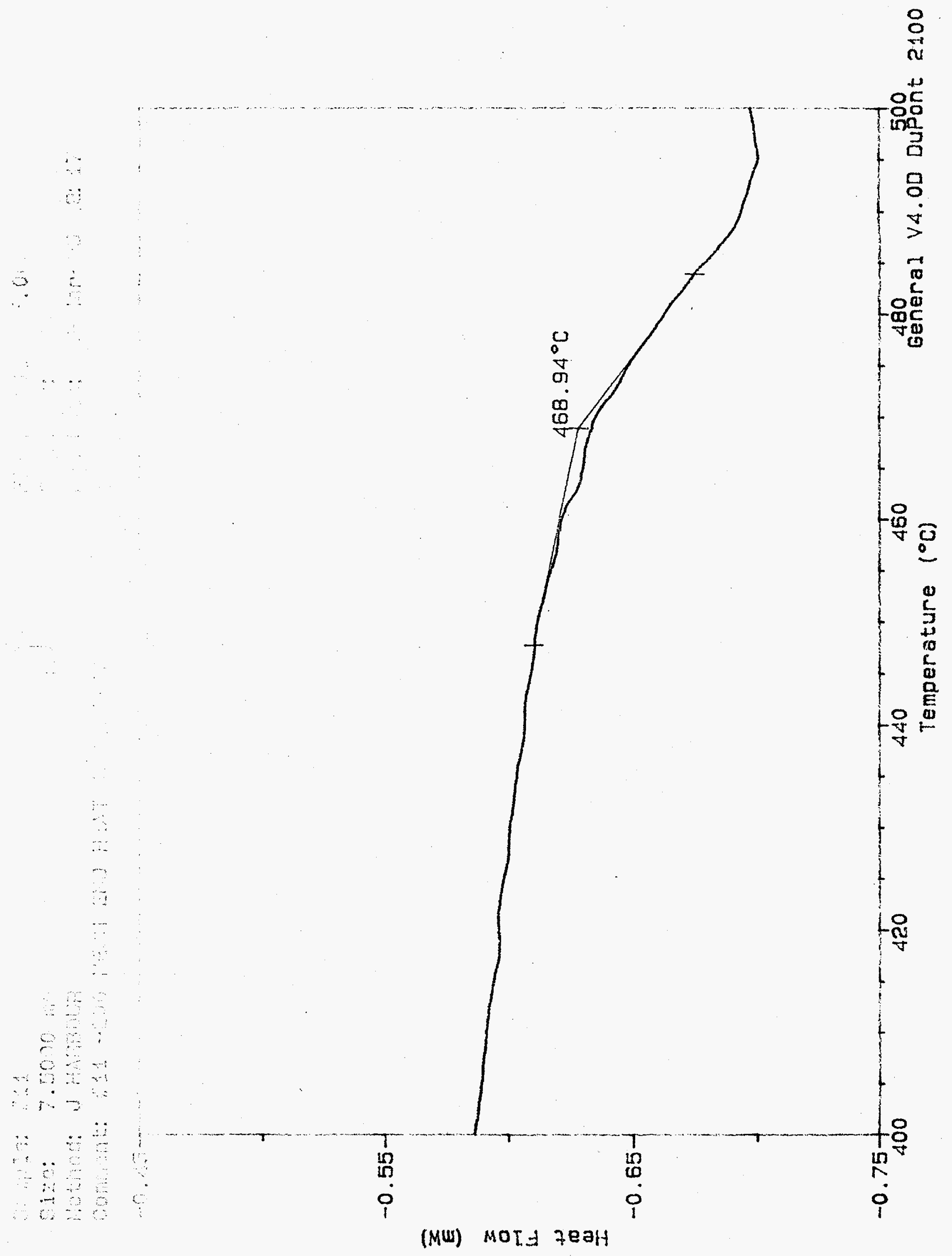




\section{Samp 1e: \#36}

Size: $\quad 3.8000 \mathrm{mg}$

Method: J HAABOUA

Comment: \#36 -200 MESH FIRST HEAT TREATMENT

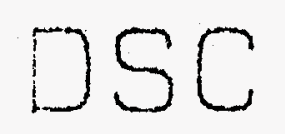

File: C: 36DWPF.002

Operator: JWC

Run Date: 14-Mar-95 05: 20

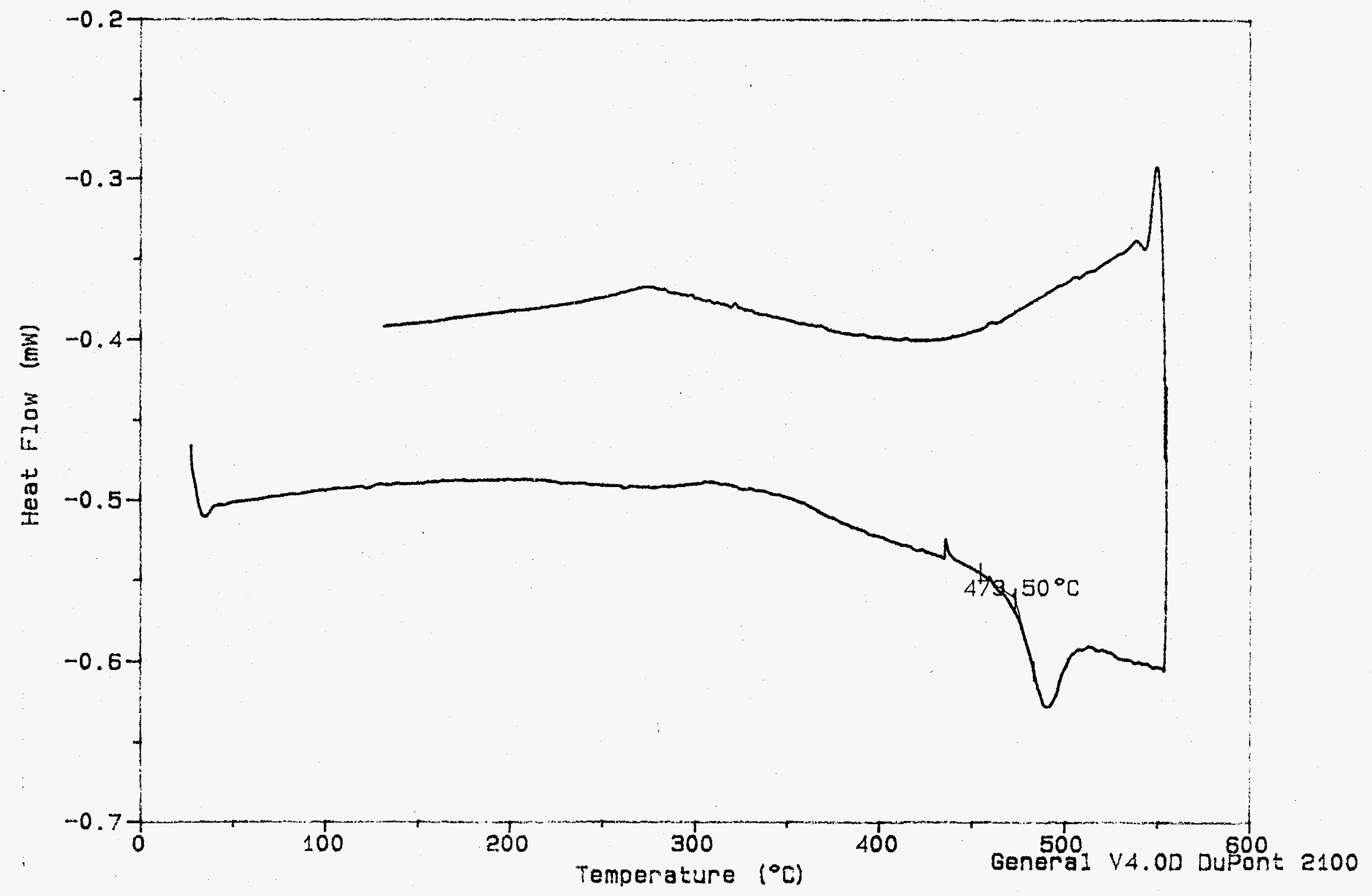




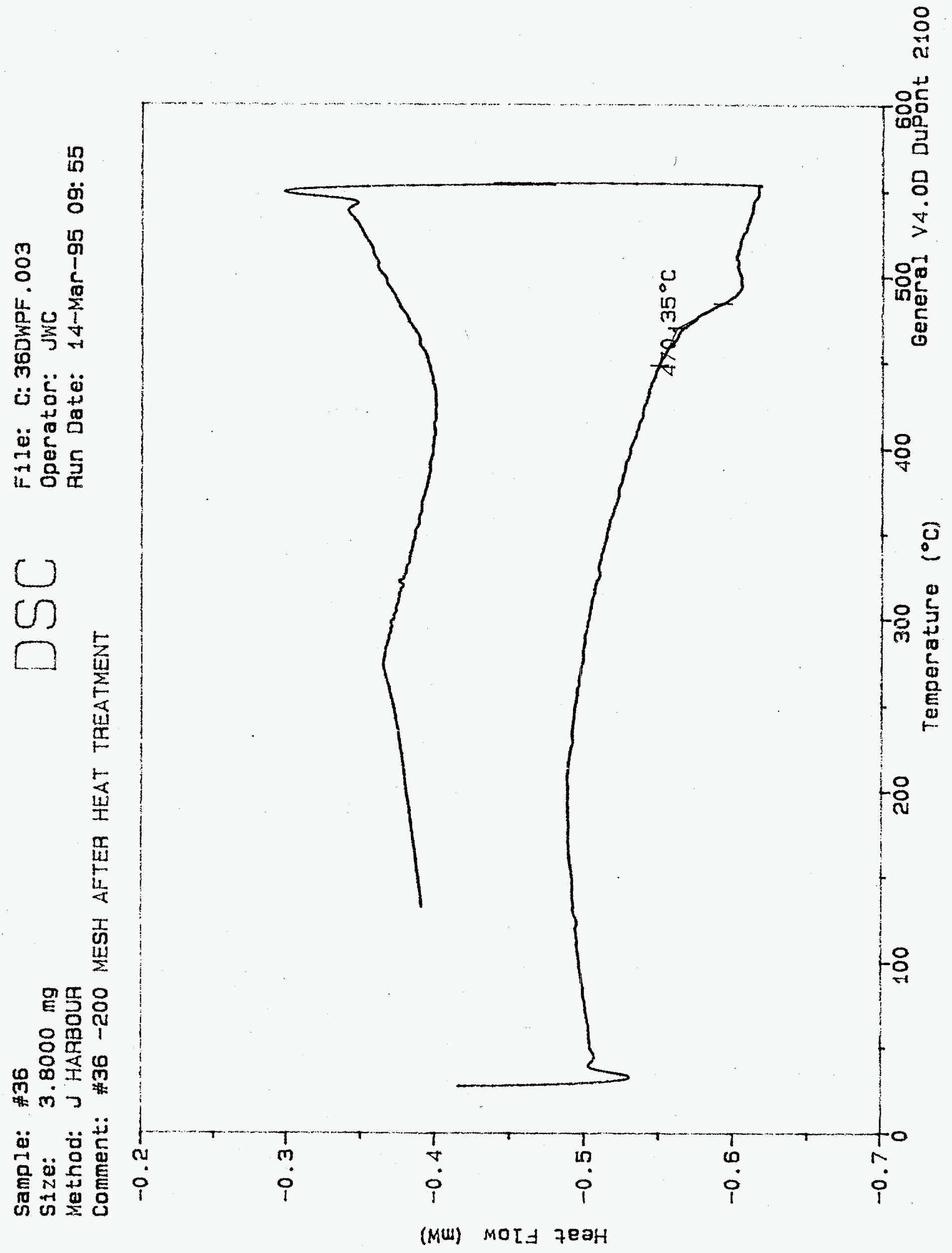




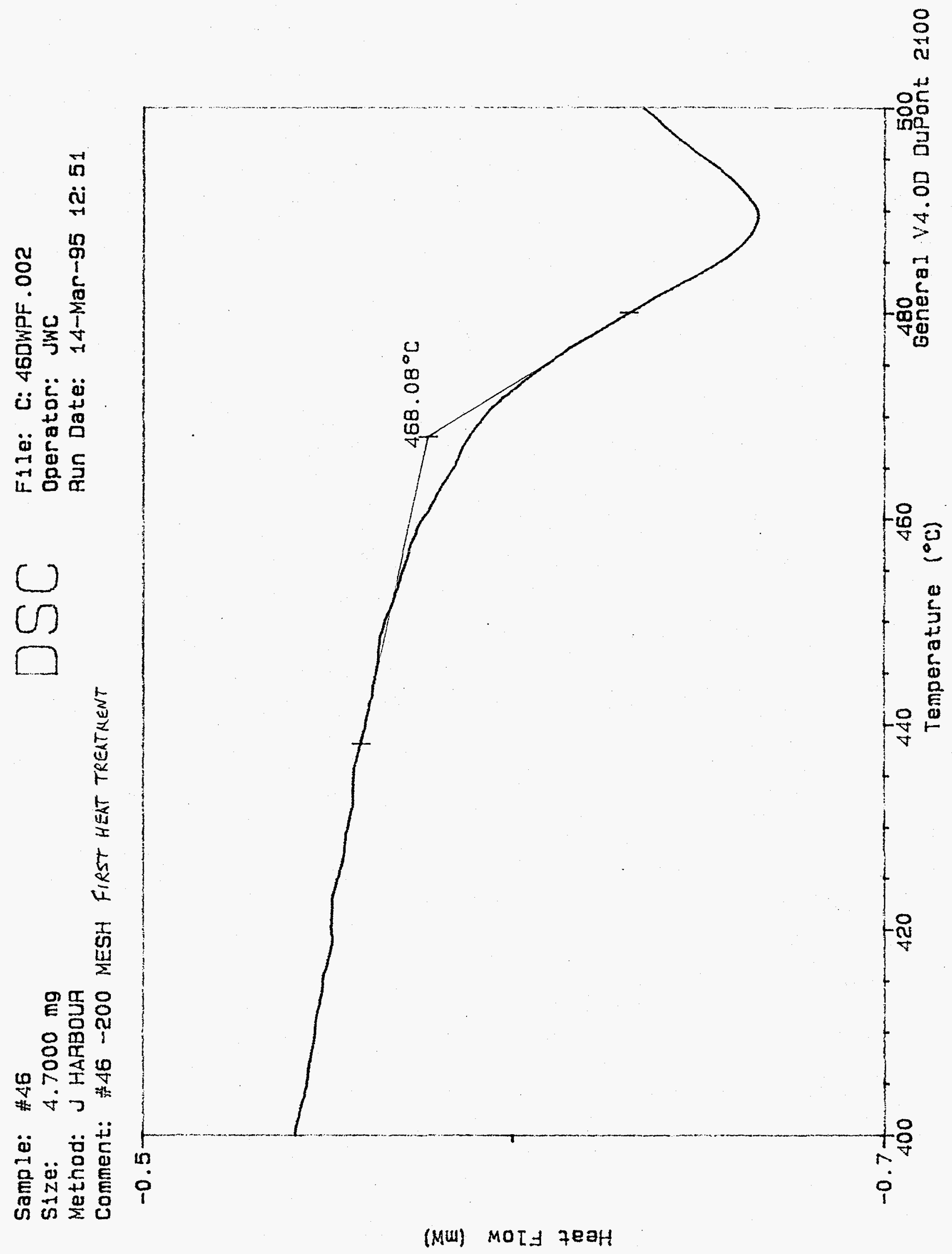




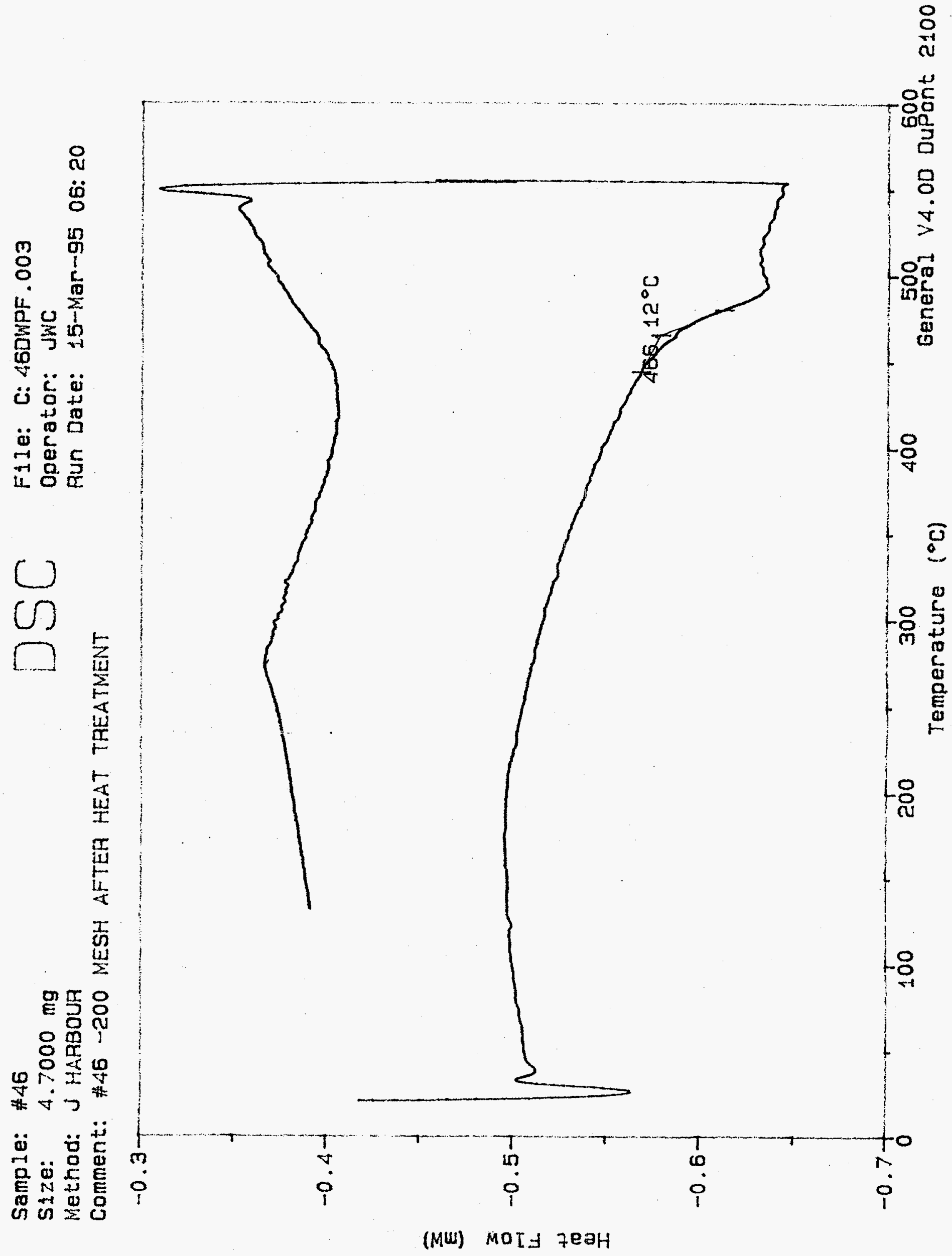




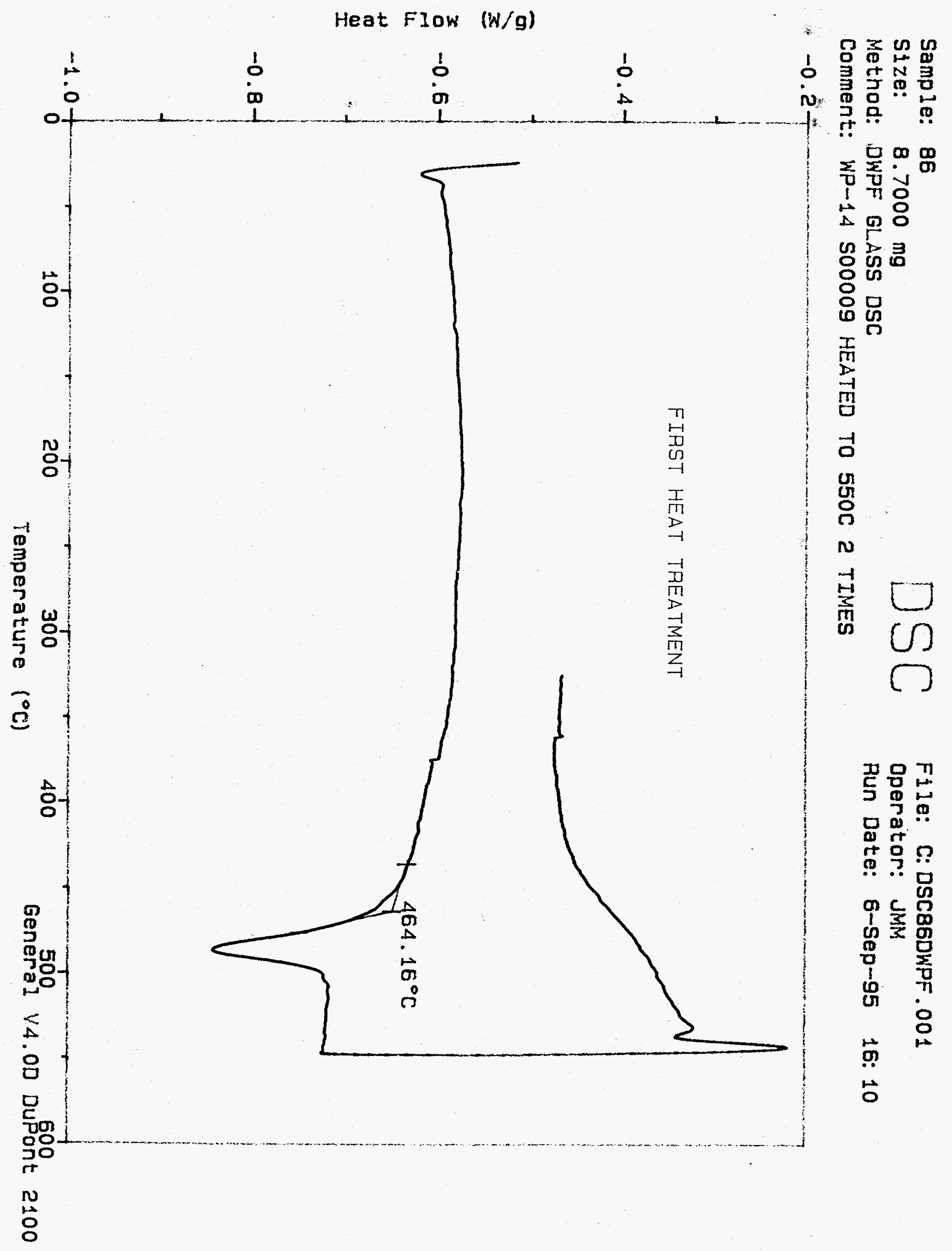

$51^{d}$ 


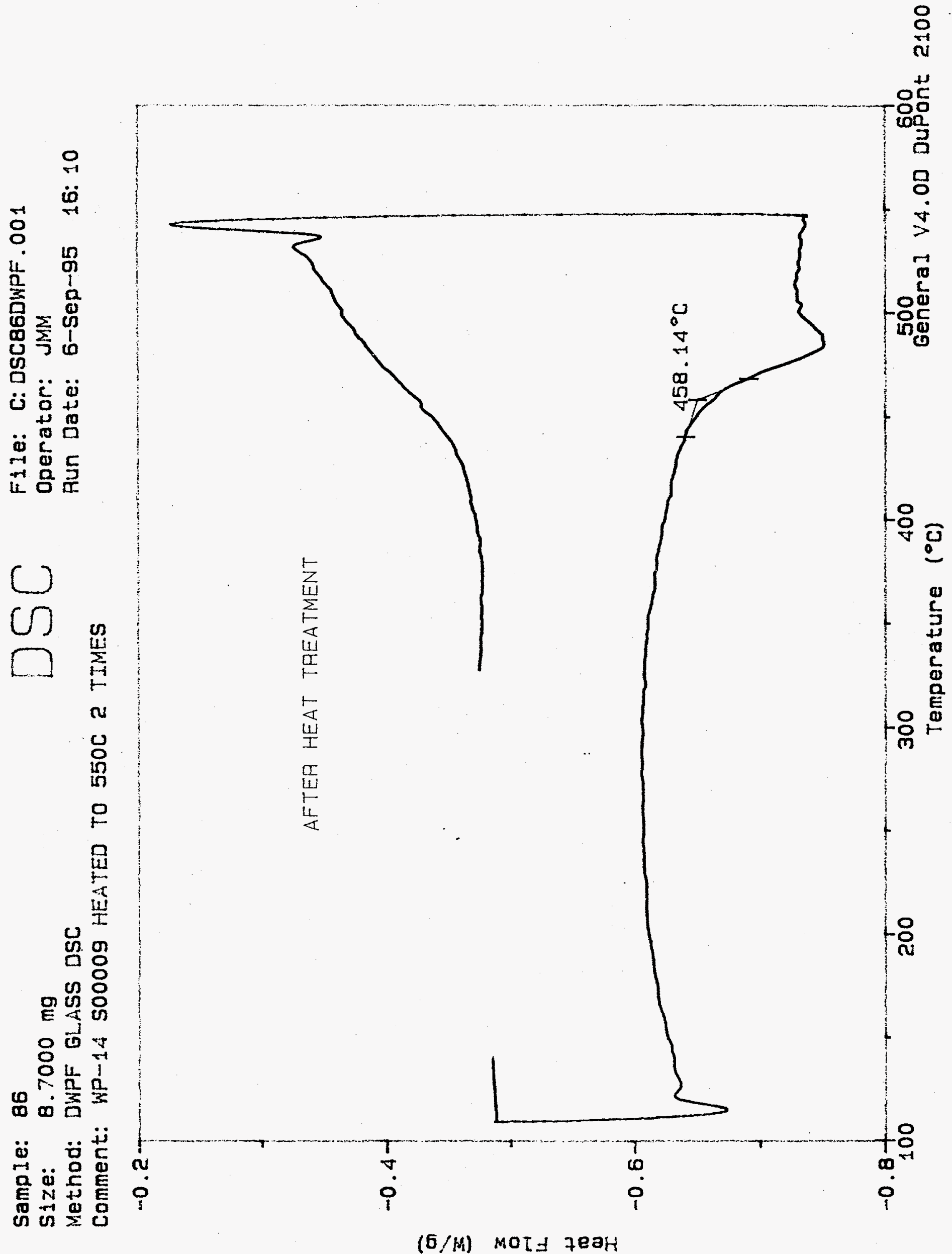




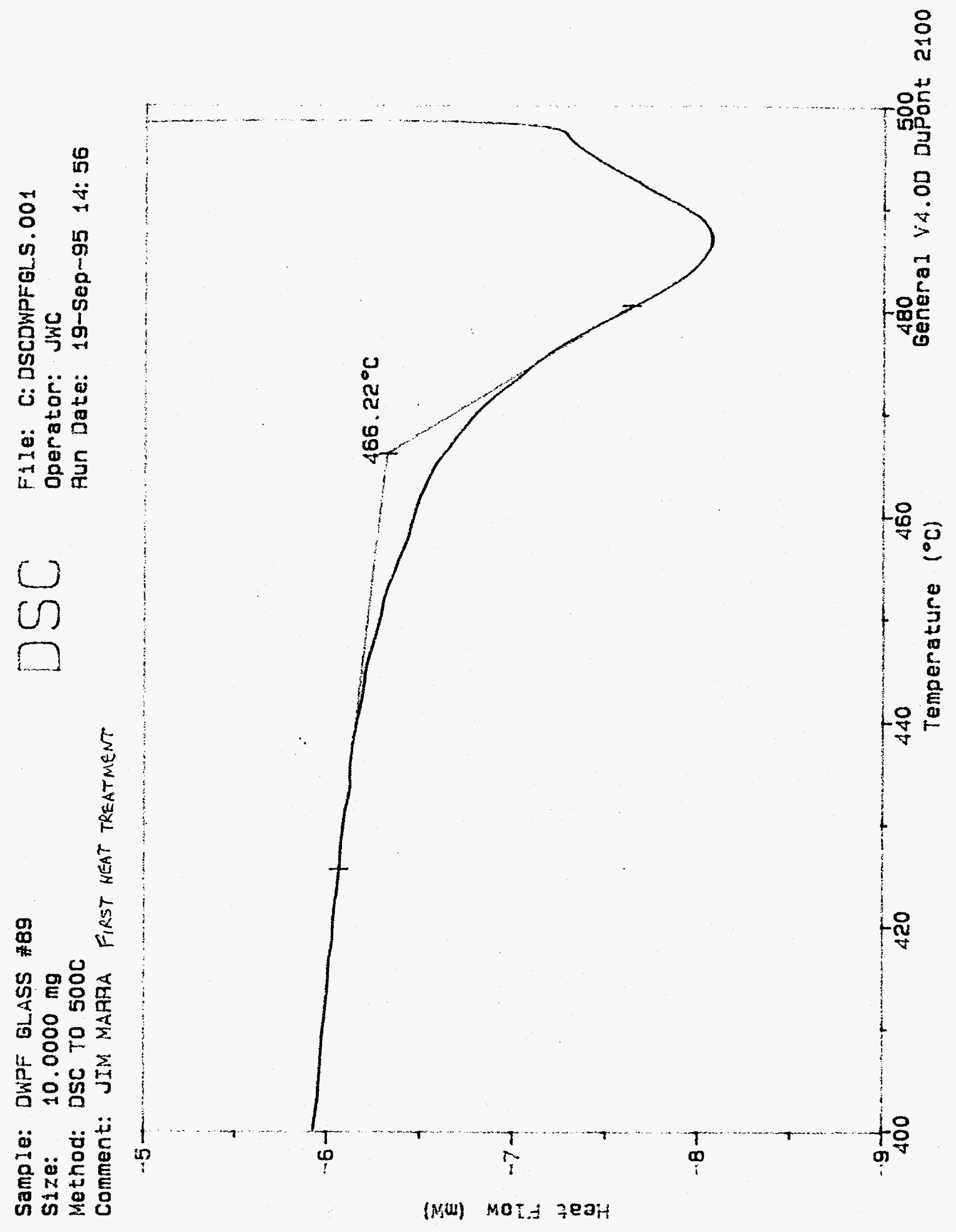


Samp 1e: DWPF GLASS \#89

S1ze: $\quad 10.0000 \mathrm{mg}$

DSC

File: C: DSCDWPFGLS.002

Method: DSC TO 500C

Operator: JWC

Comment: JIM MARRA AFTER. WEAT TREATMENT

Fun Date: 20-Sep-95 06: 50

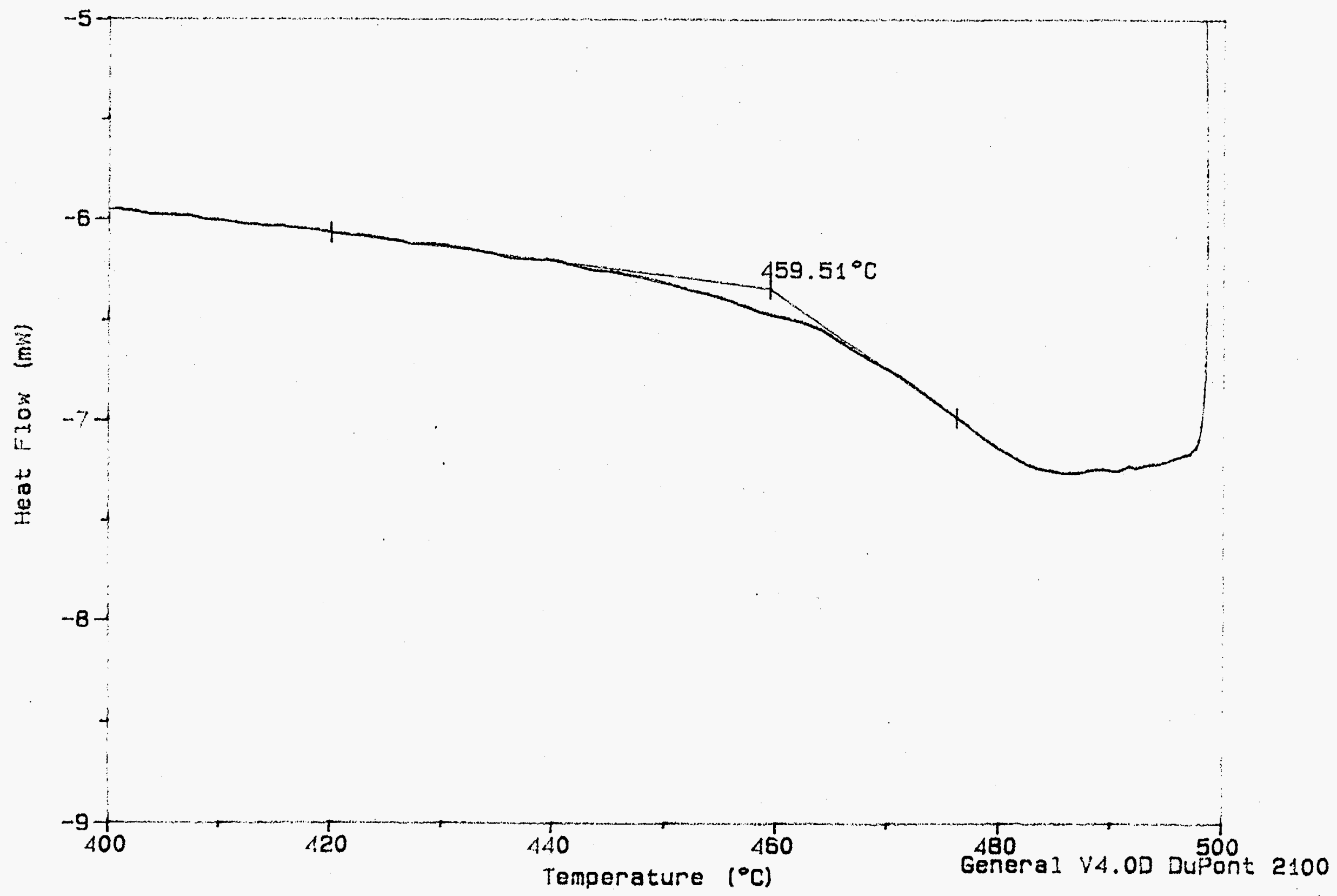


Sample: 104

Size: $\quad 5.6000 \mathrm{mg}$

Method: DWPF GLASS DSC

Comment: WP-14 S00155
DSC

File: C: DSC104DWPF.002

Operator: JMM

Run Date: 11-Sep-95 13: 34

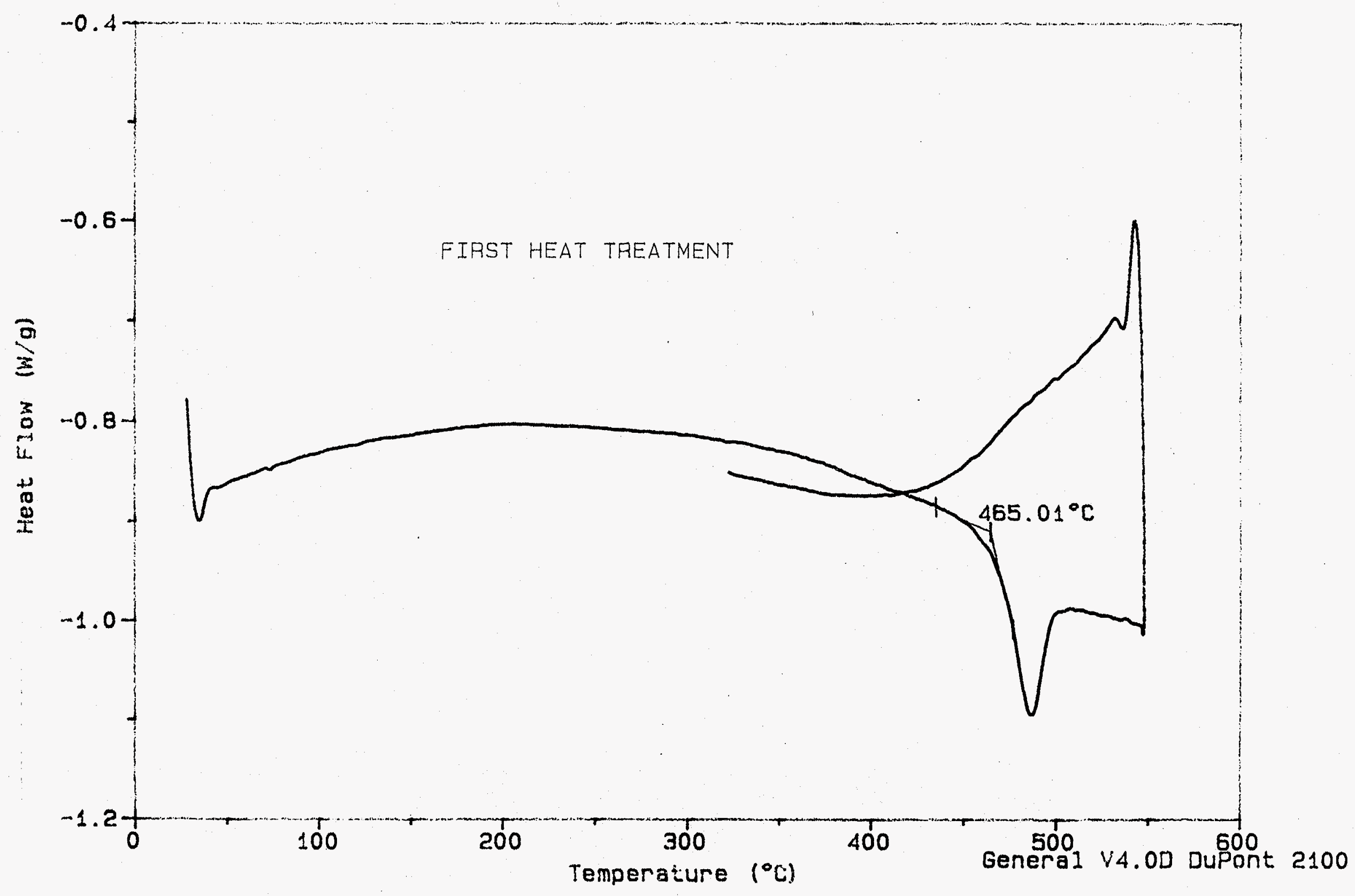


Sample: 104

Size: $\quad 5.6000 \mathrm{mg}$

Method: DWPF GLASS DSC

Comment: WP-14 S00155

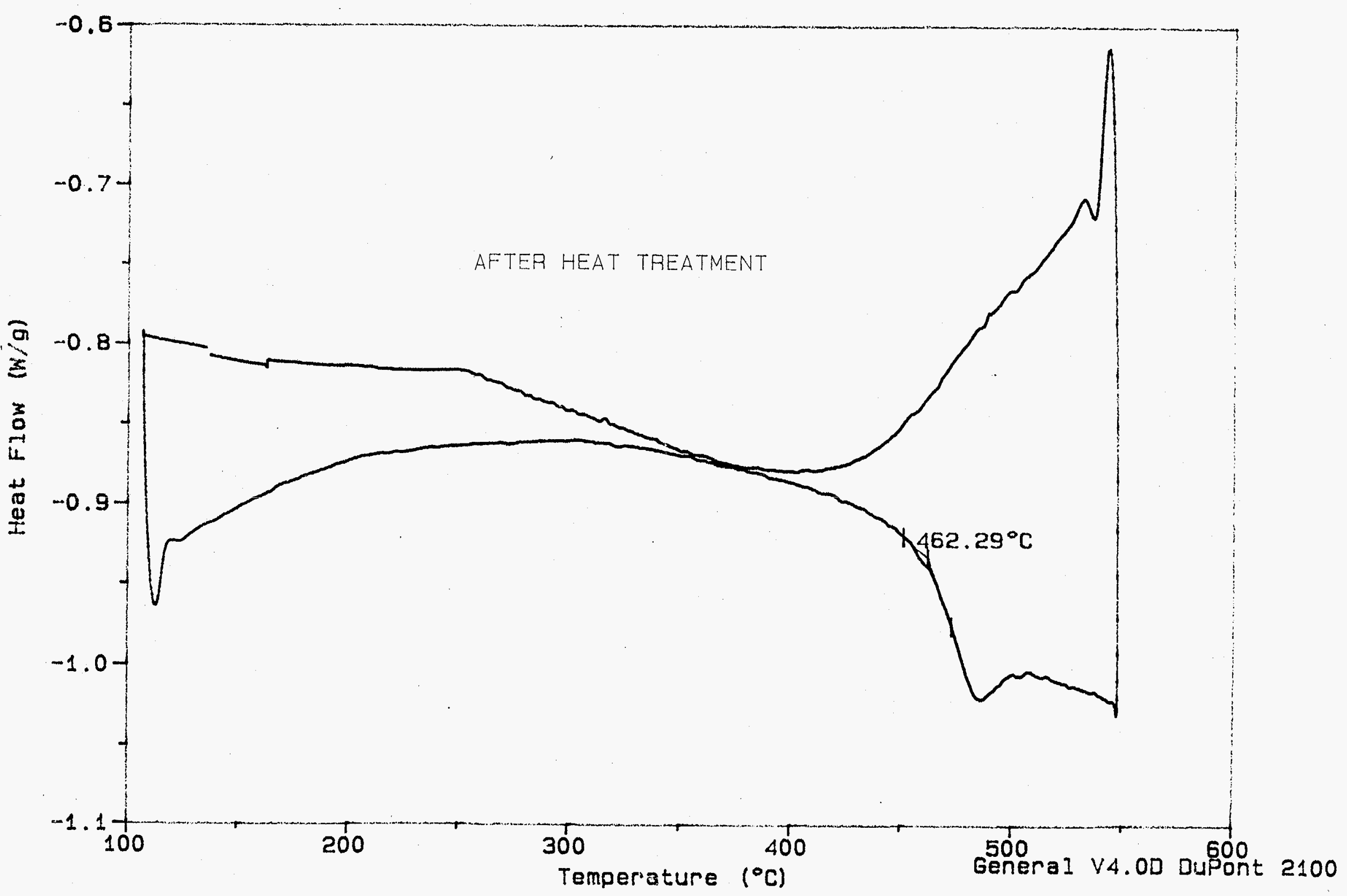

F1le: C: DSC104DWPF.002

Operator: JMM

Fun Date: 11-Sep-95 13: 34 
Sample: 214

Size: $\quad 5.2000 \mathrm{mg}$

Method: DWPF GLASS DSC

Comment: WP-15 500179
DSC

File: C: DSC214DWPF.001

Operator: JMM

Run Date: 8-Sep-95 12:03

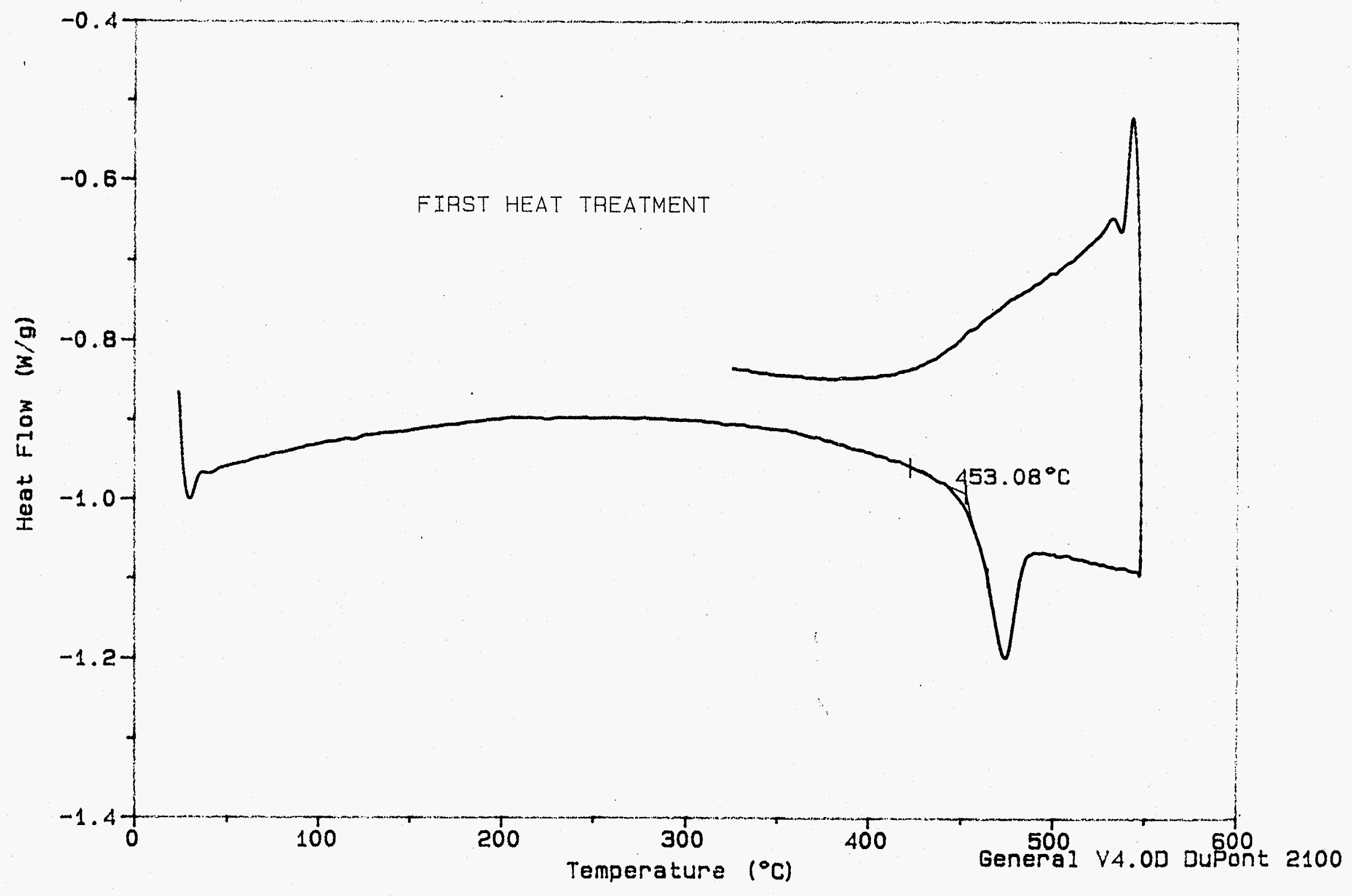

r 
Samp 1e: 214

Size: $\quad 5.2000 \mathrm{mg}$

Method: DWPF GLASS DSC

Comment: WP-15 500179

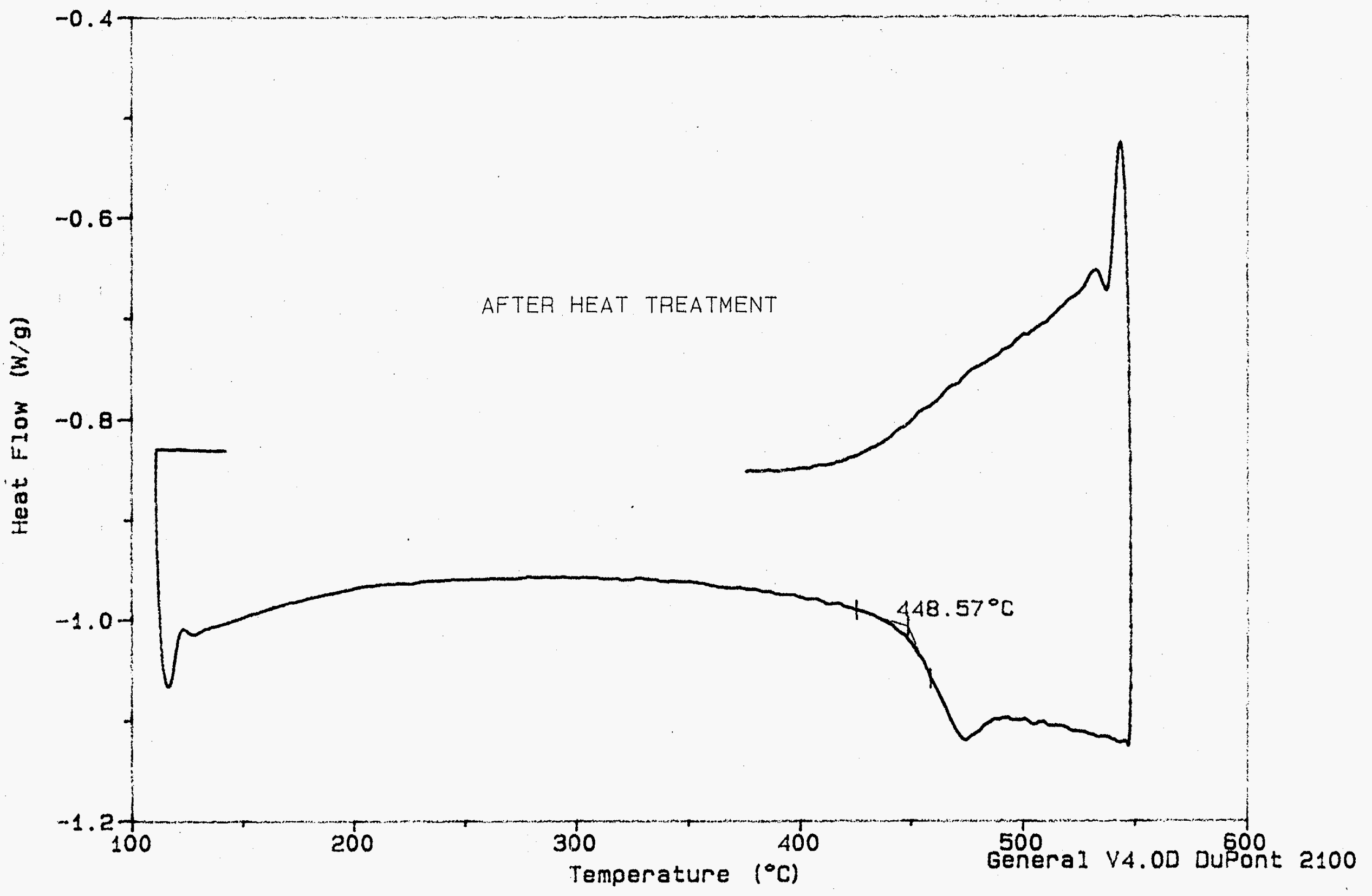

File: C: DSC214DWPF.001

Operator: JMM

Run Date: 8-Sep-95 12:03 


\section{Samp 1e: 222}

Size: $\quad 7.7000 \mathrm{mg}$

Method: DWPF GLASS DSC

Comment: WP-15 S00181

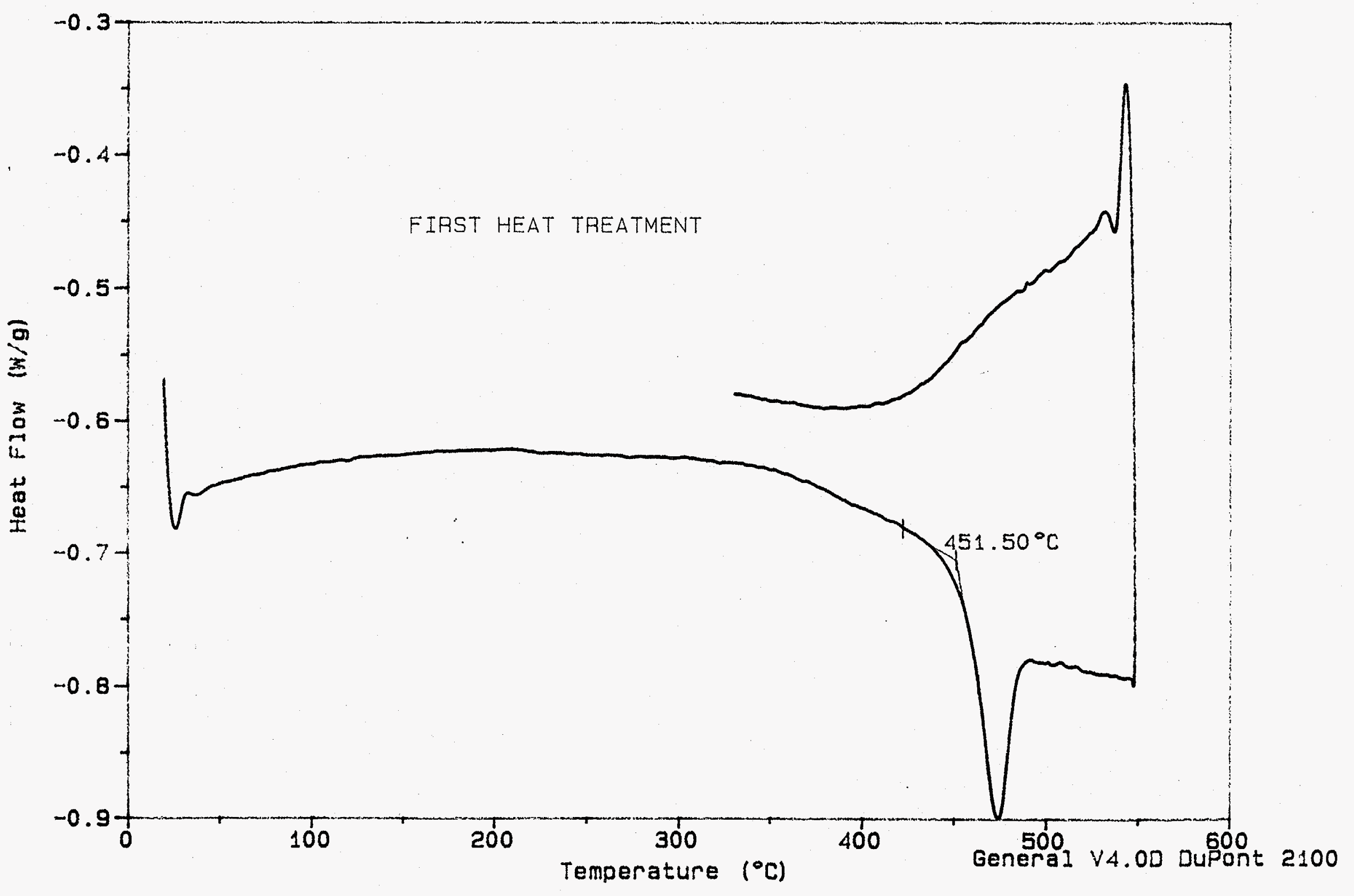

File: C: DSC222DWPF.002

Operator: JMM

Fun Date: 12-Sep-95 09: 17 


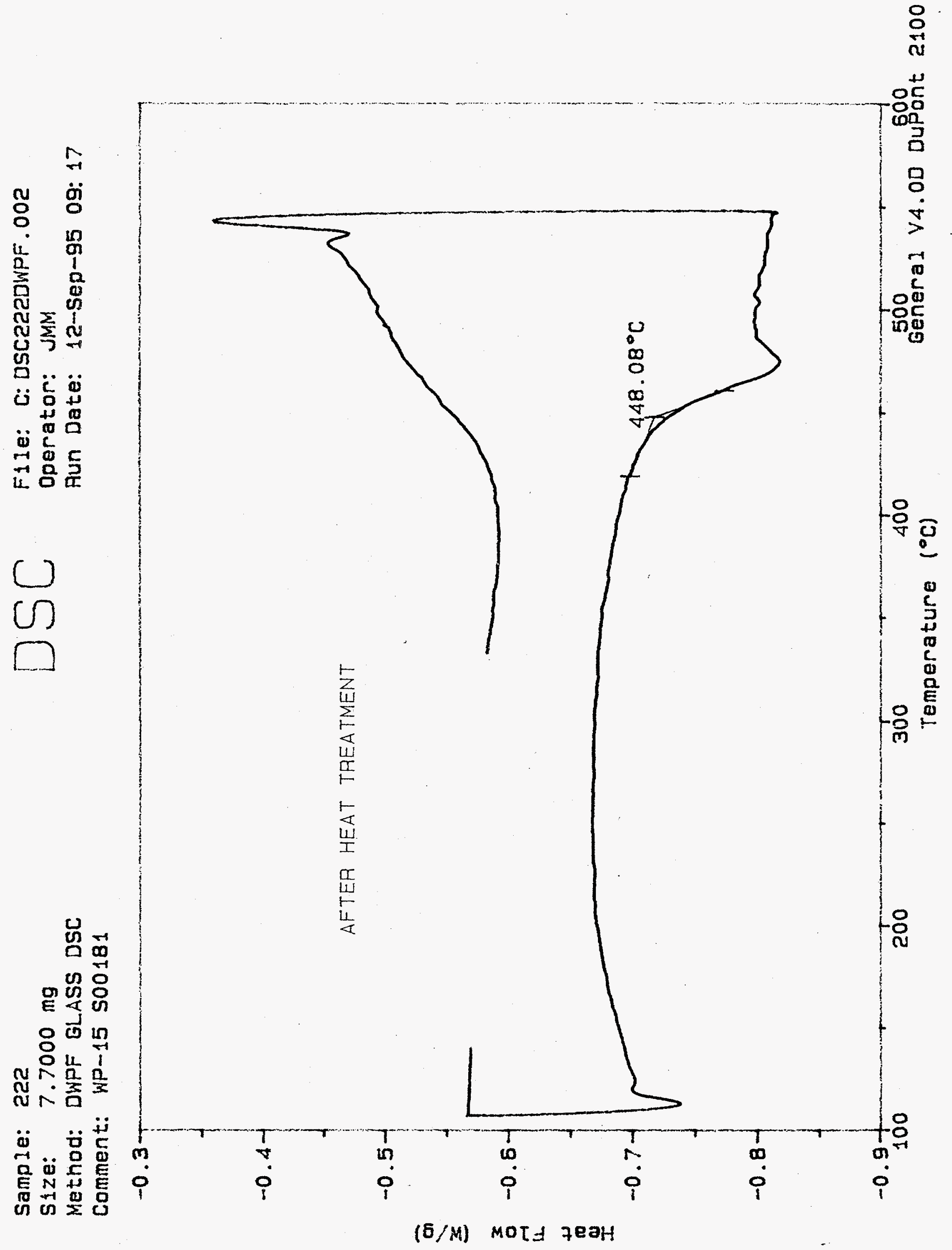


$\rho^{.25}$

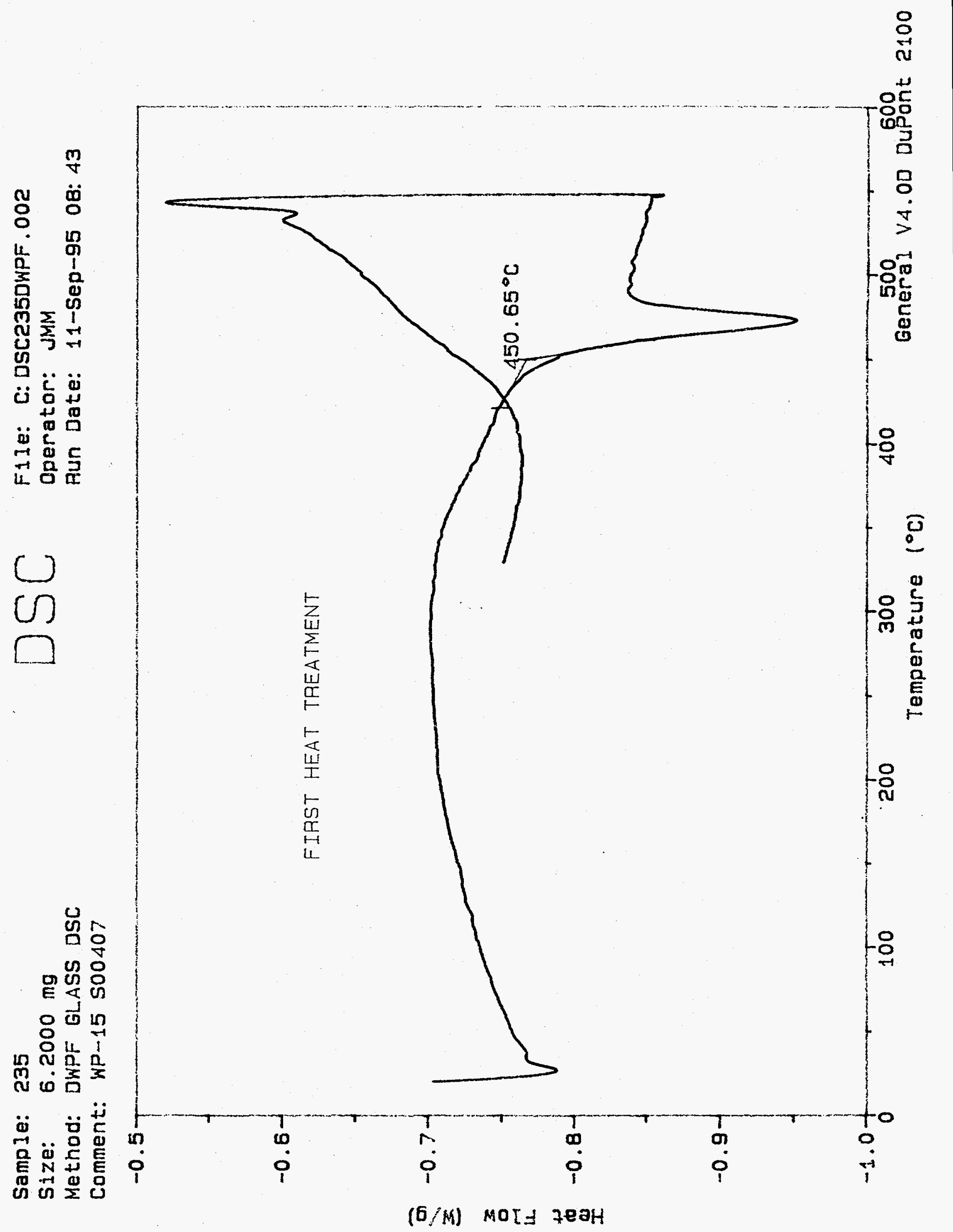




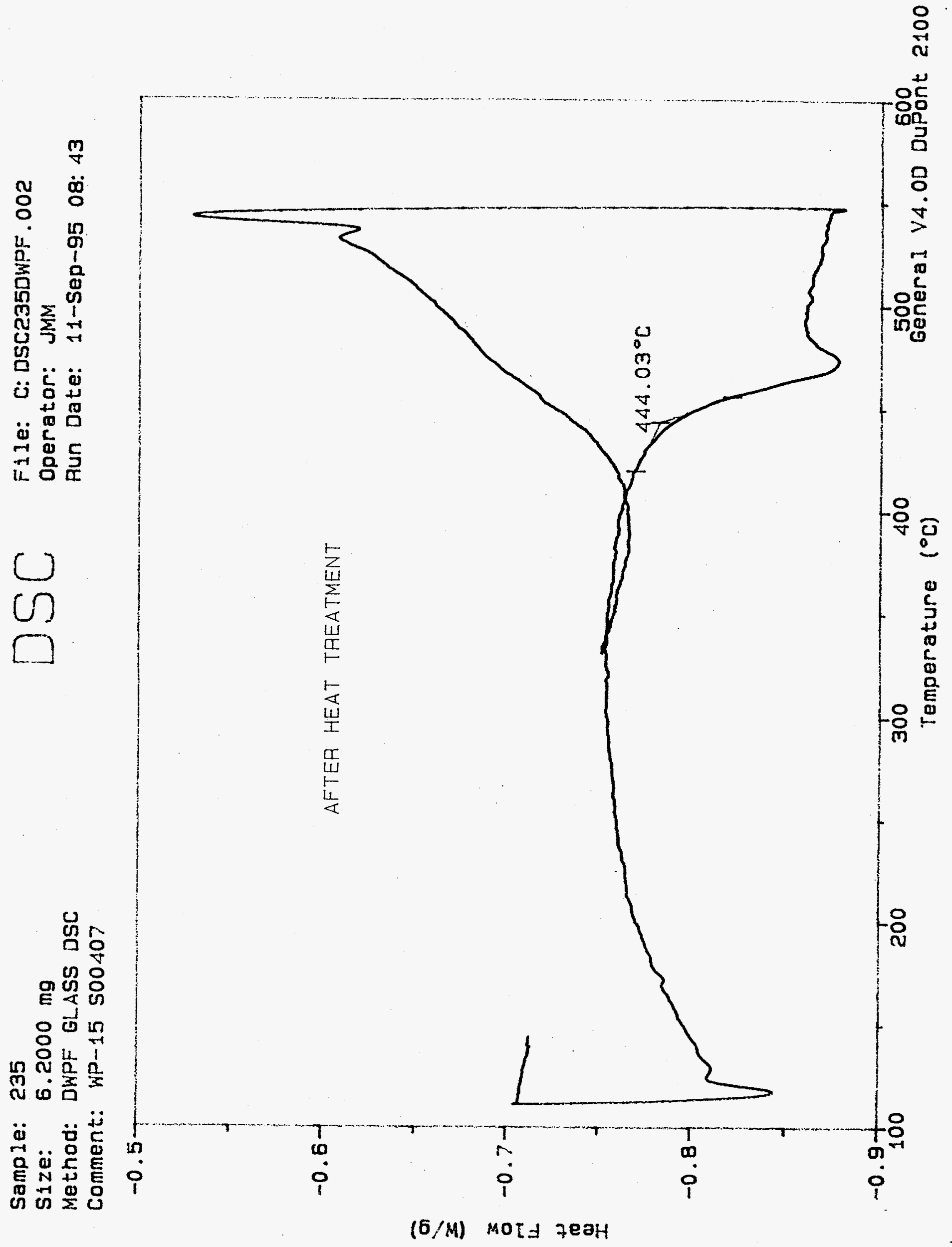


$p .27$

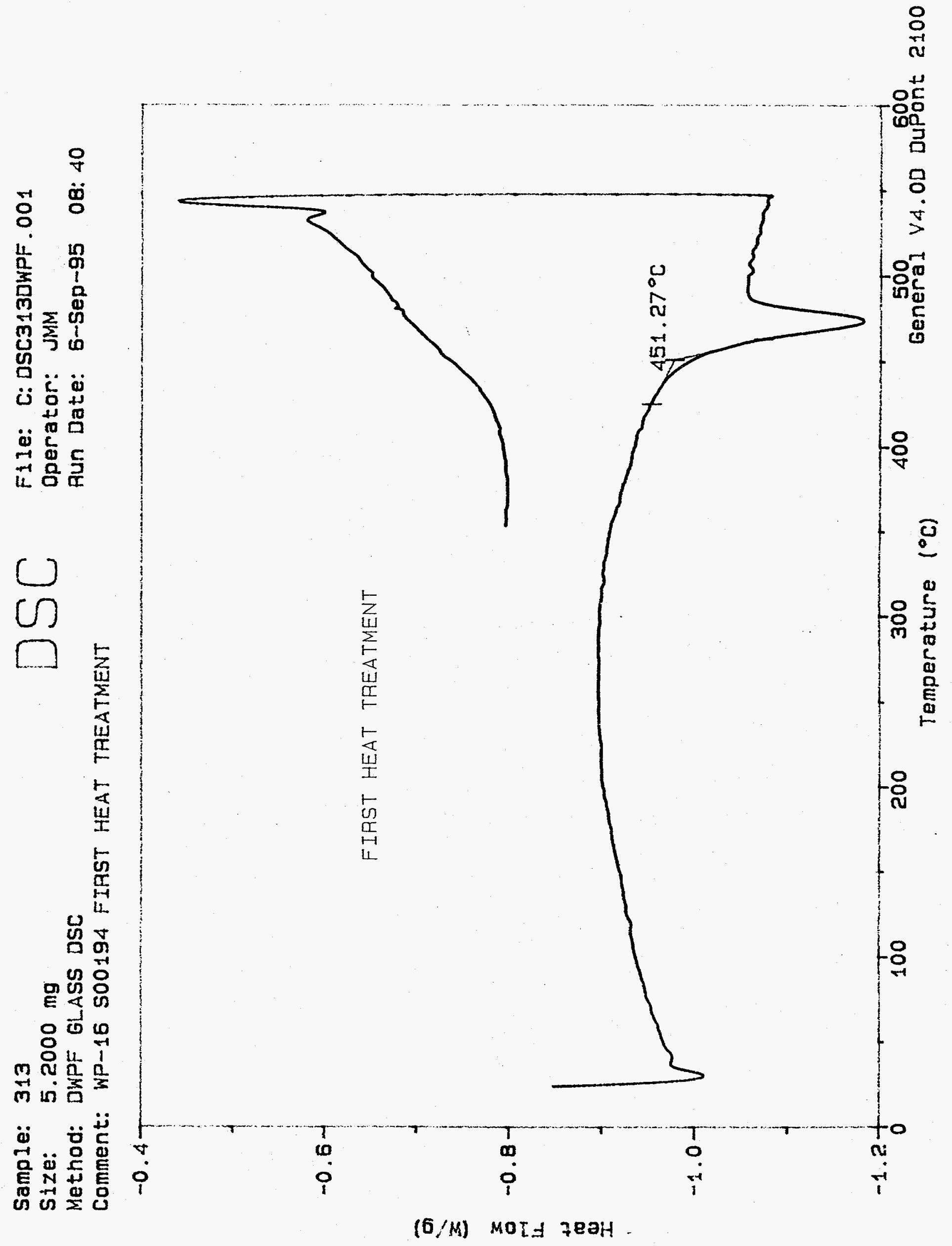




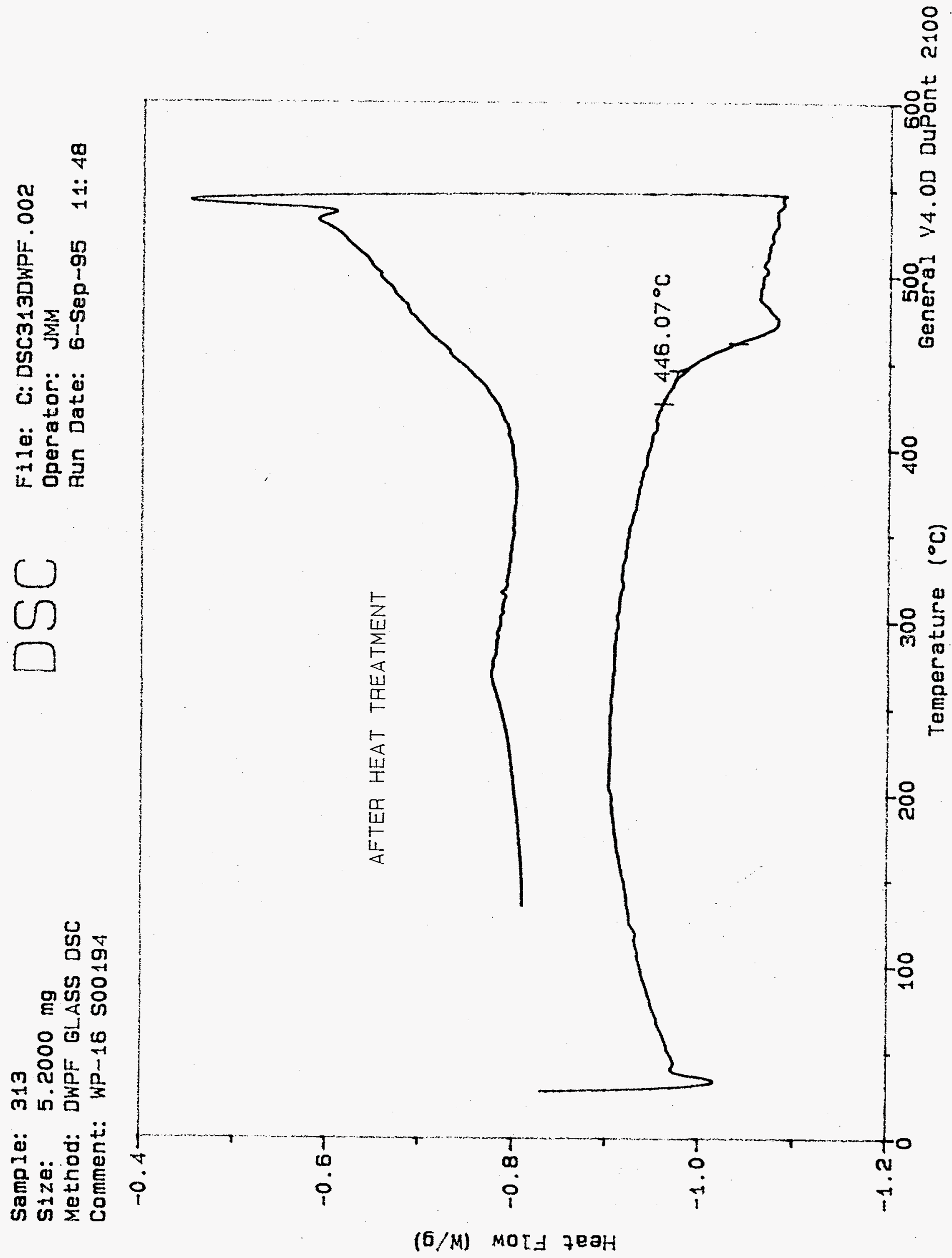


$p .29$

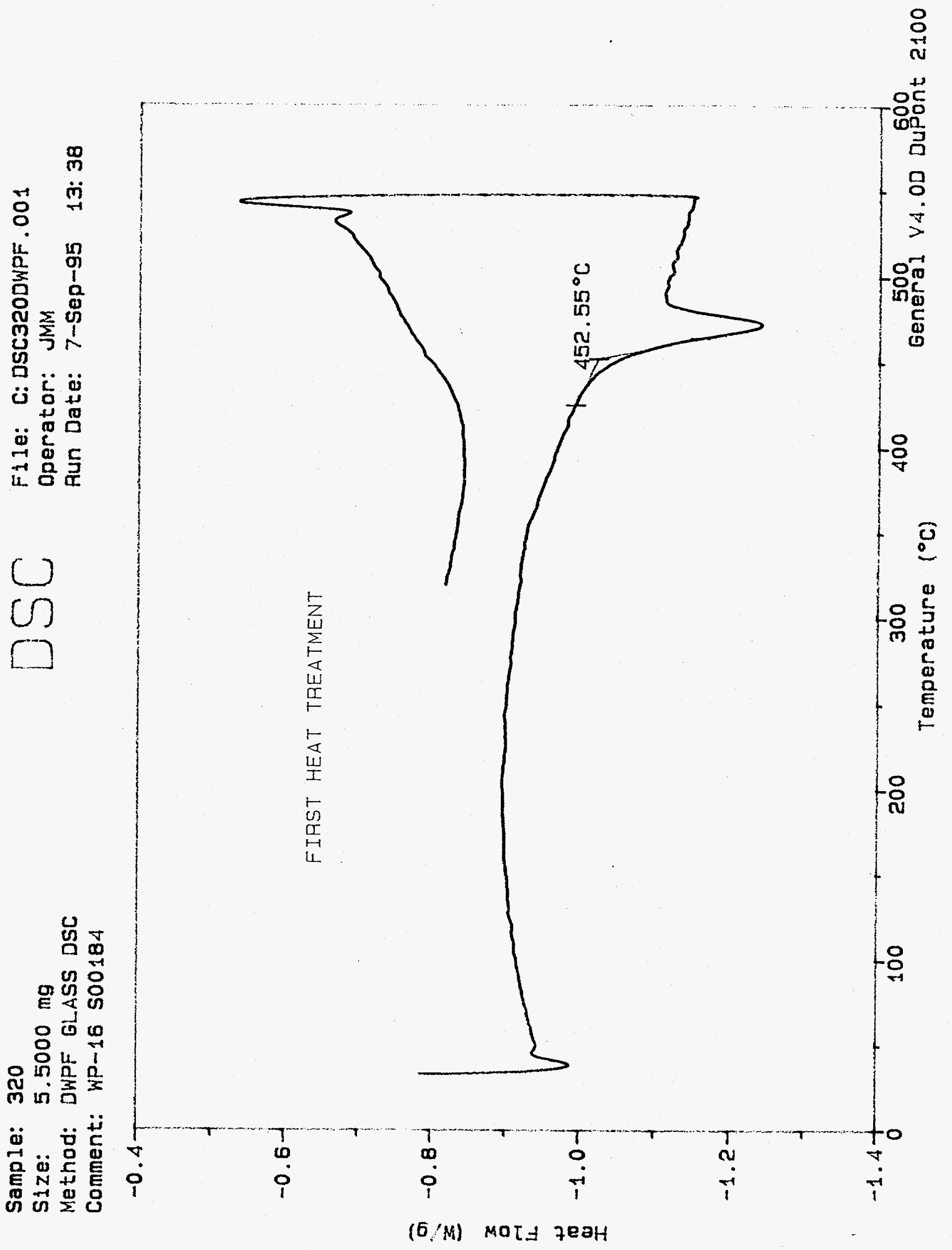




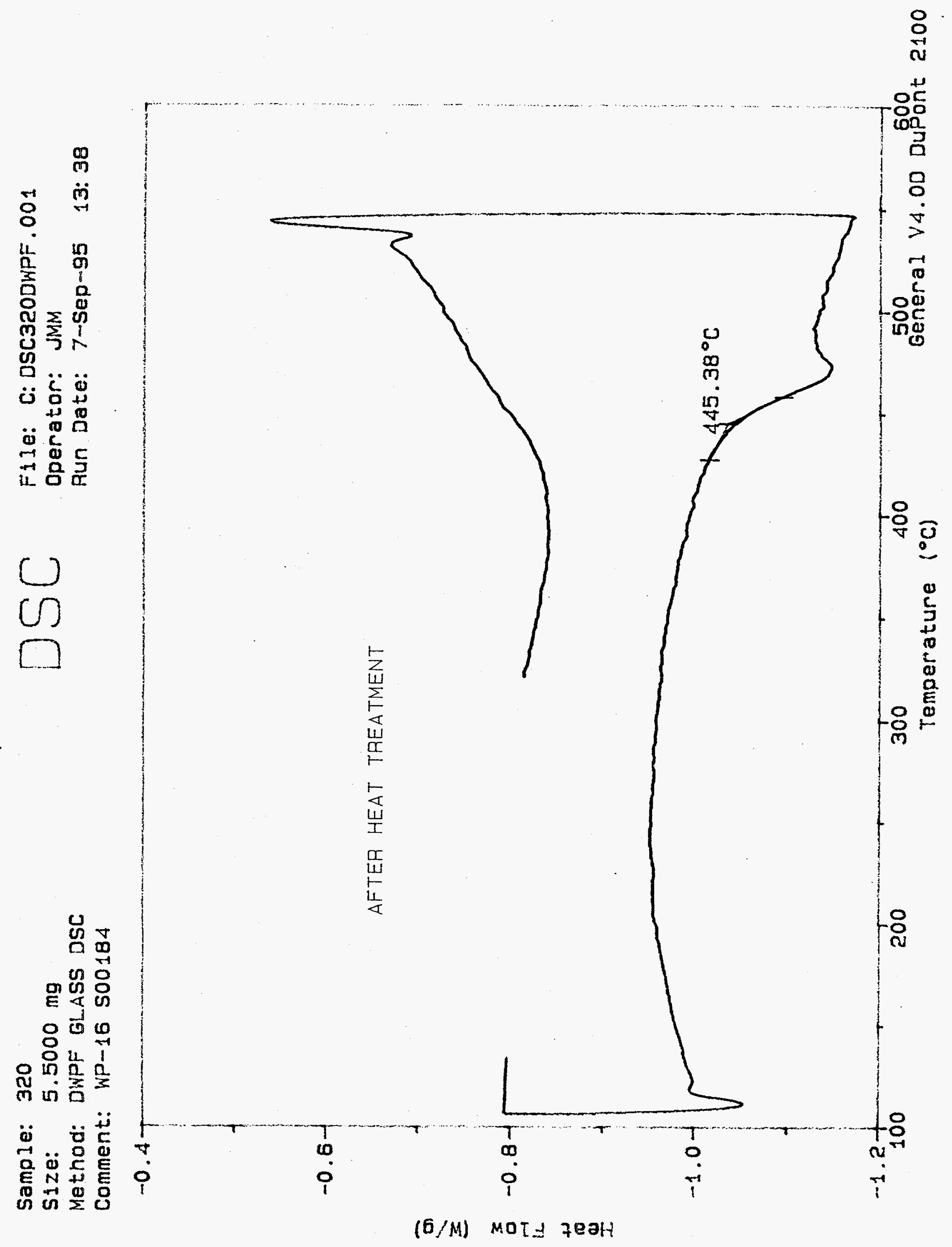


$p \cdot 31$

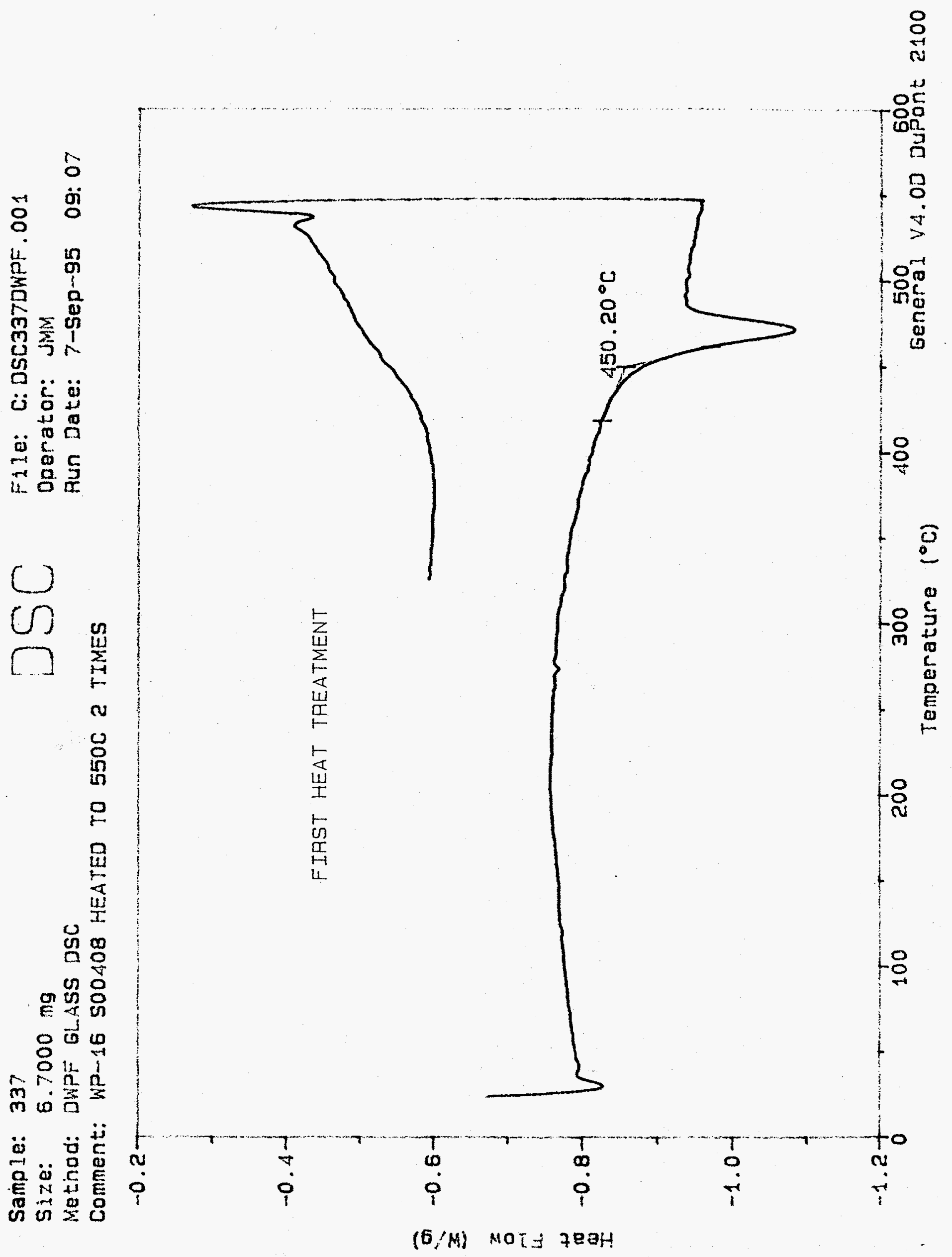


Sample: 337

Size: $\quad 6.7000 \mathrm{mg}$

Method: DWPF GLASS DSC

Comment: WP-16 S00408 HEATED TO 550C 2 TIMES

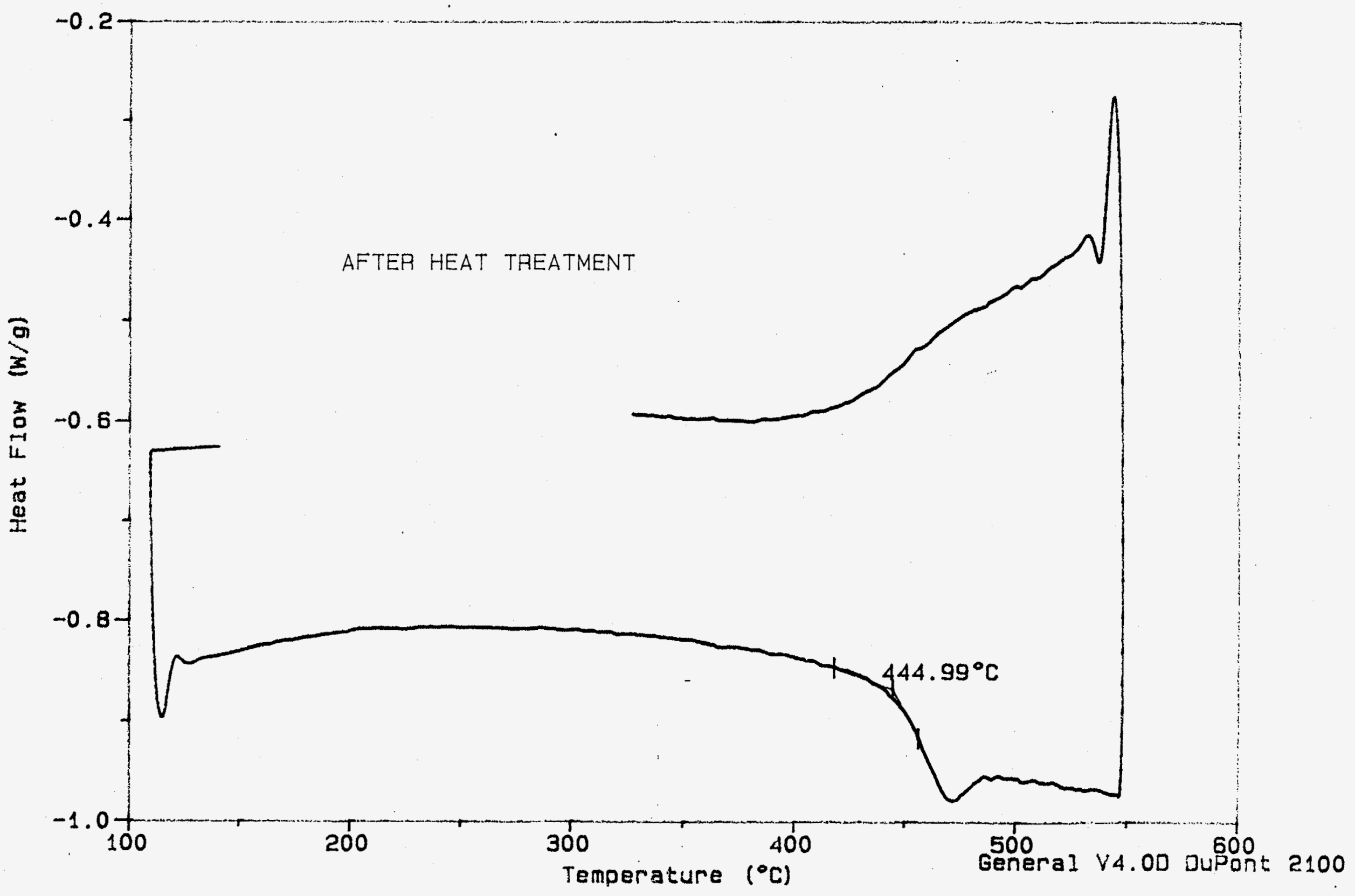

Fi1e: C: DSC337DWPF.001

Operator: JMM

Run Date: 7-Sep-95 09:07 


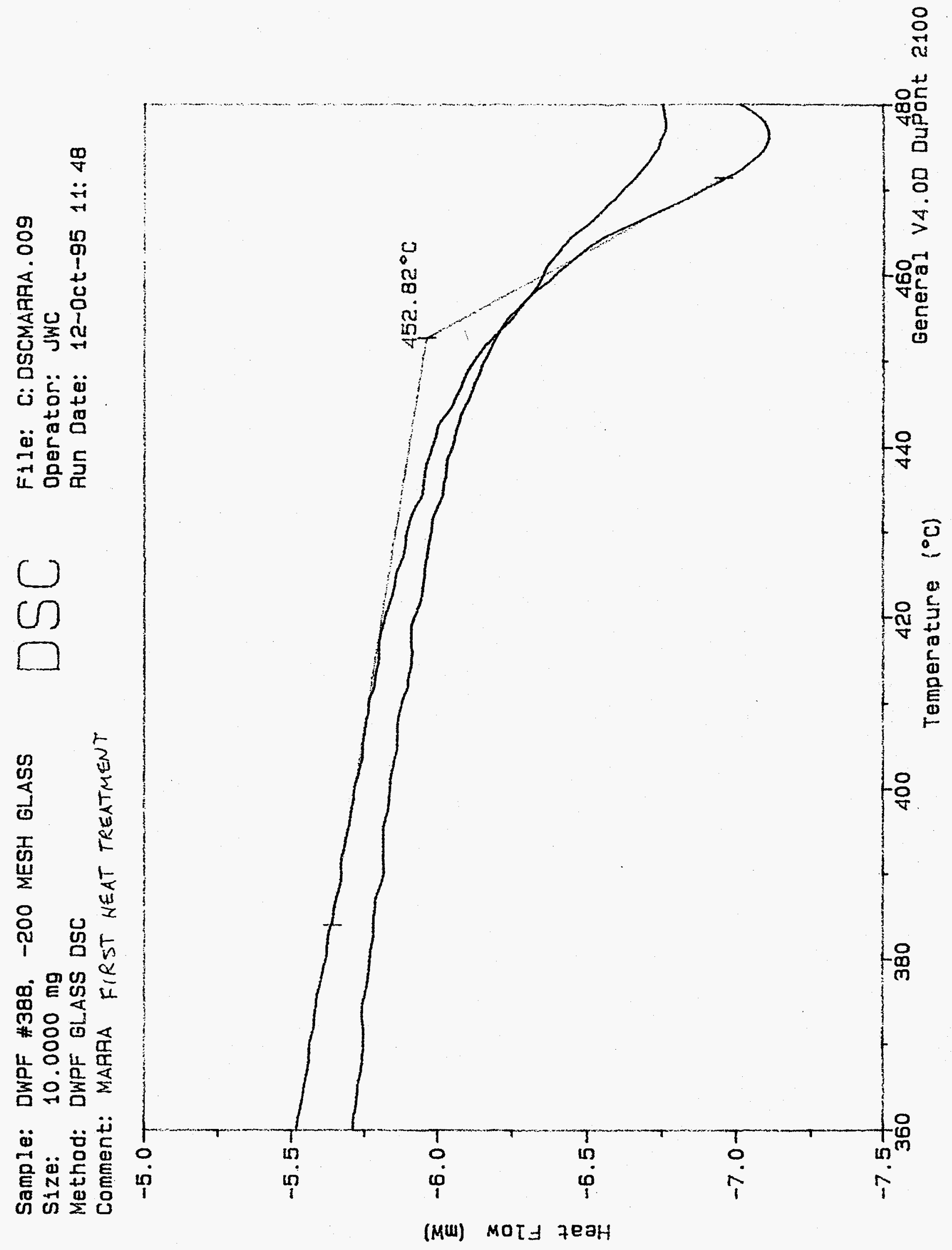




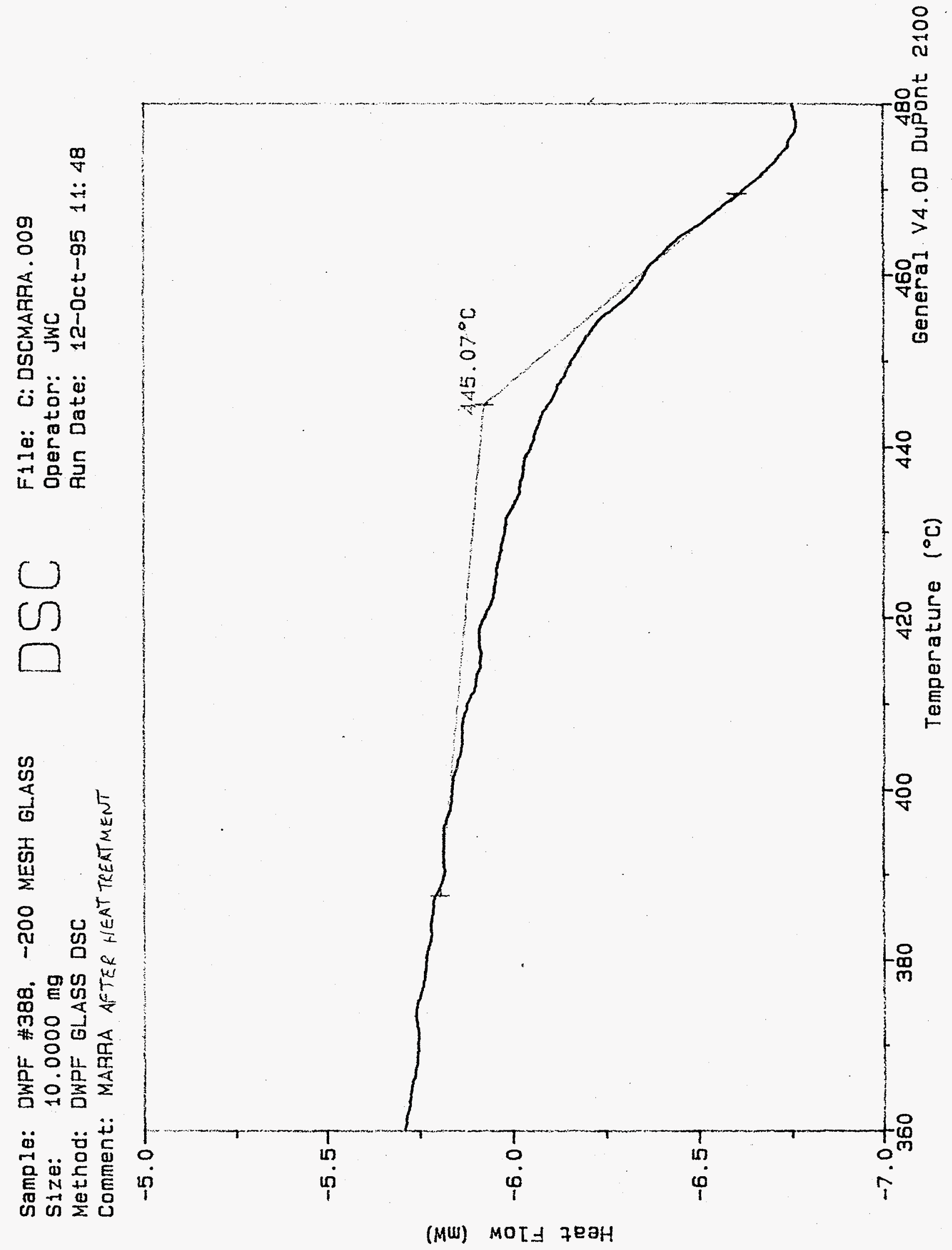




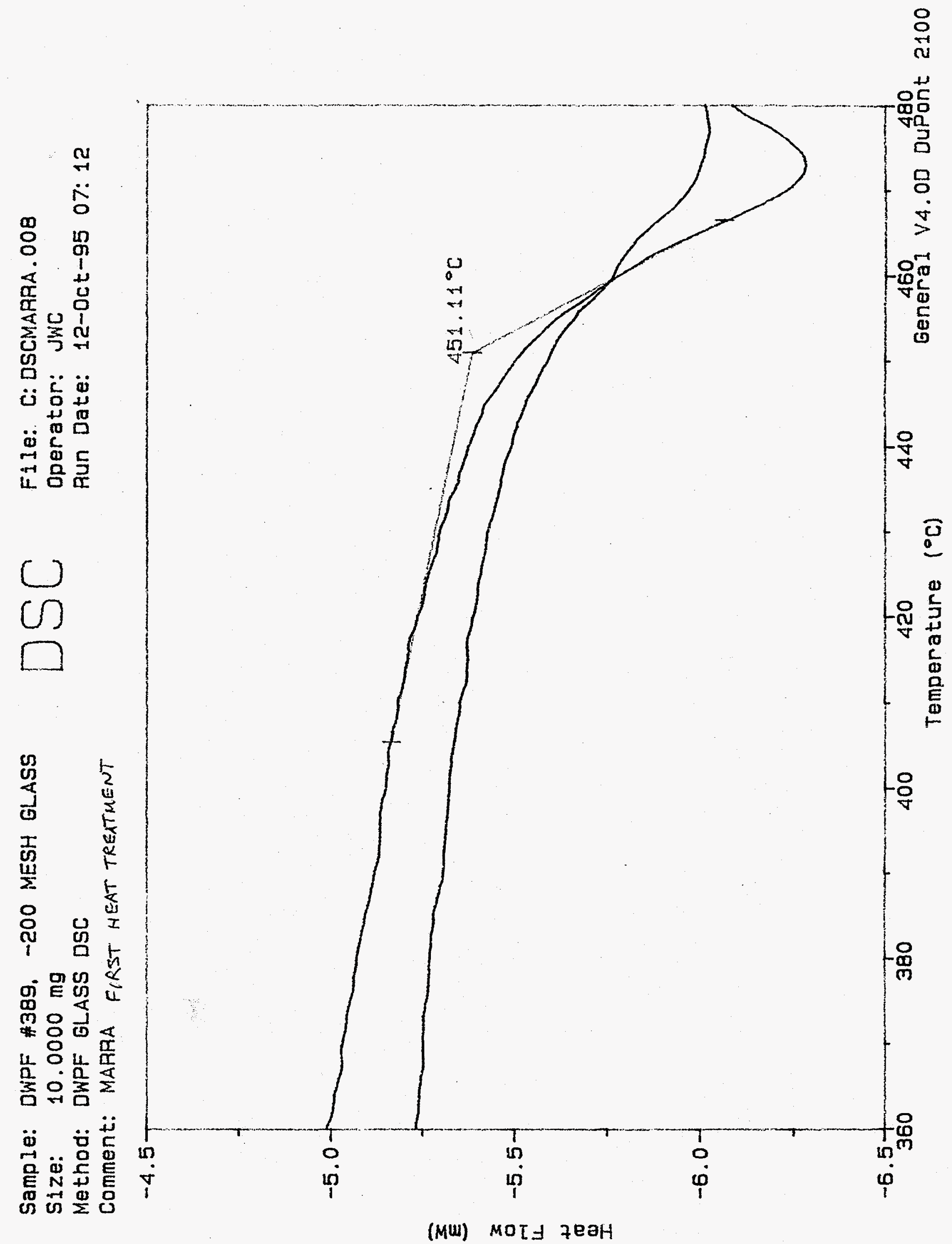


Samp 1e: DWPF \#389, -200 MESH GLASS

Size: $\quad 10.0000 \mathrm{mg}$

Method: DWPF GLASS DSC

Comment: MARRA AFTER HEAT TREATMENT
DSC$$
-4 .
$$

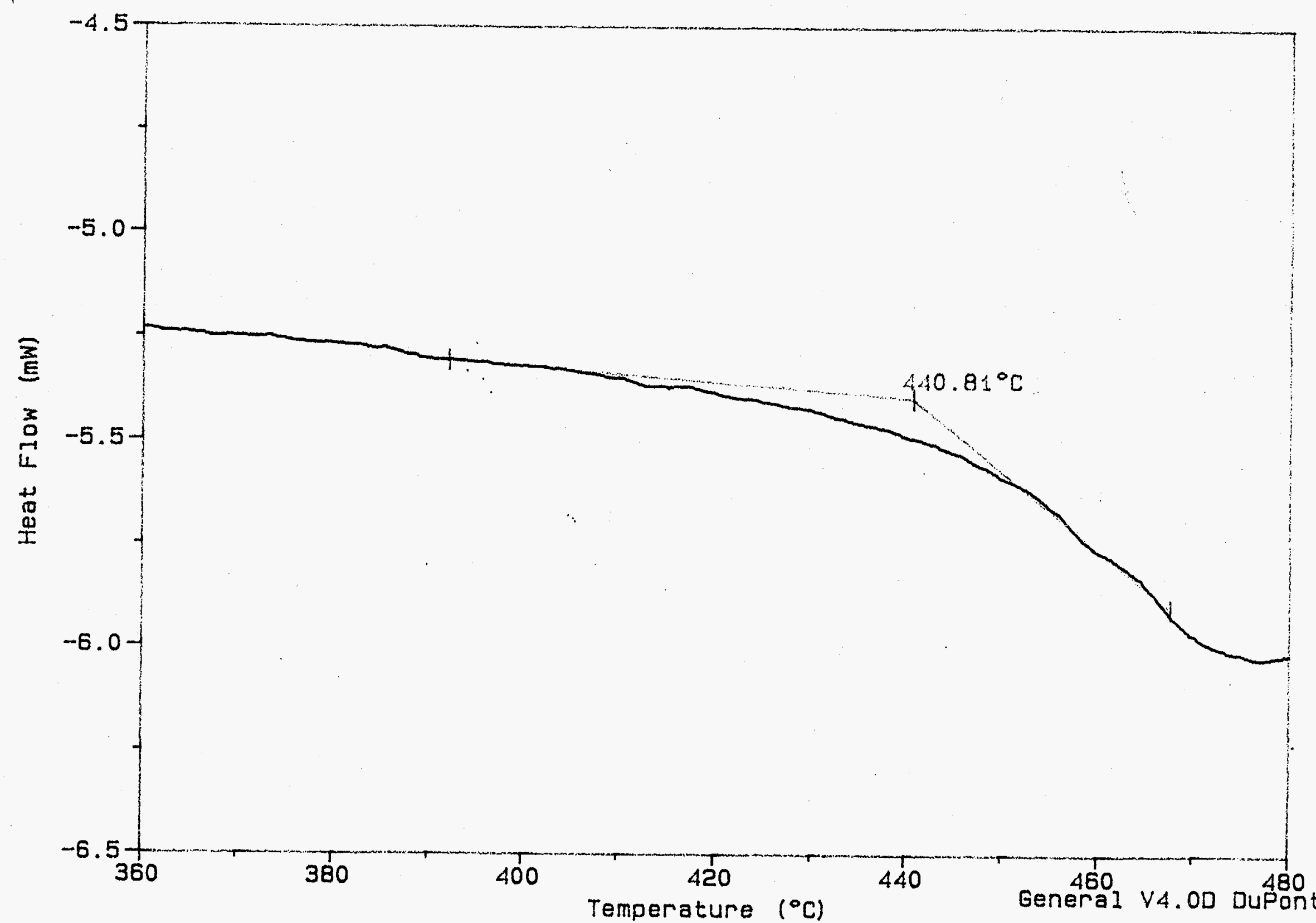

File: C: DSCMARAA. 008

Operator: JWC

Fun Date: 12-Oct-95 07: 12 
Samp 1e: DWPF \#391. -200 MESH GLASS Size: $\quad 10.0000 \mathrm{mg}$ Method: DWPF GLASS DSC

Comment: MARAA FIRST WEAT TREATMENT
DSC
File: C: DSCMAAAA.007 Operator: JWC

Fun Date: 11-0ct-95 13: 13

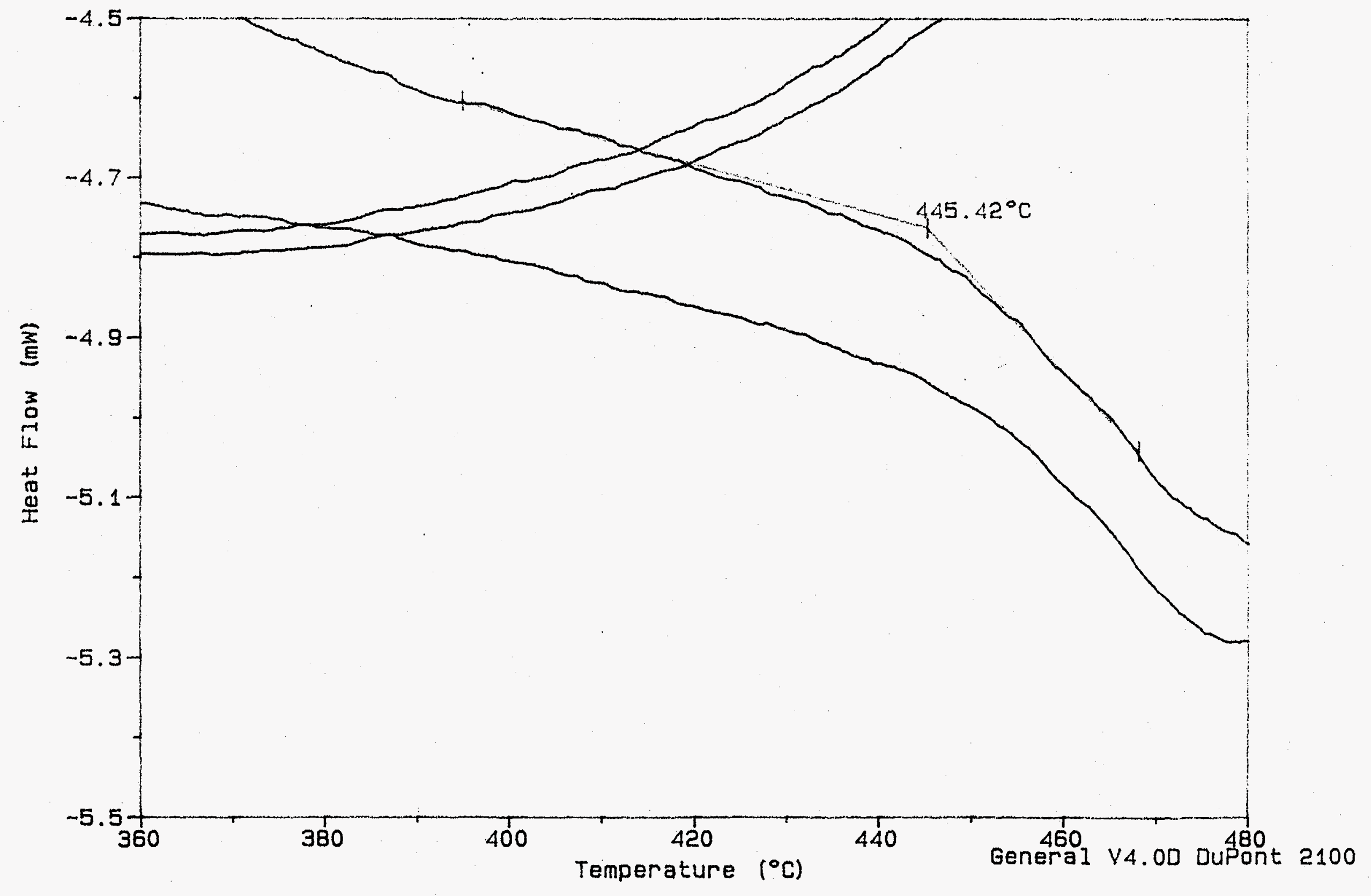




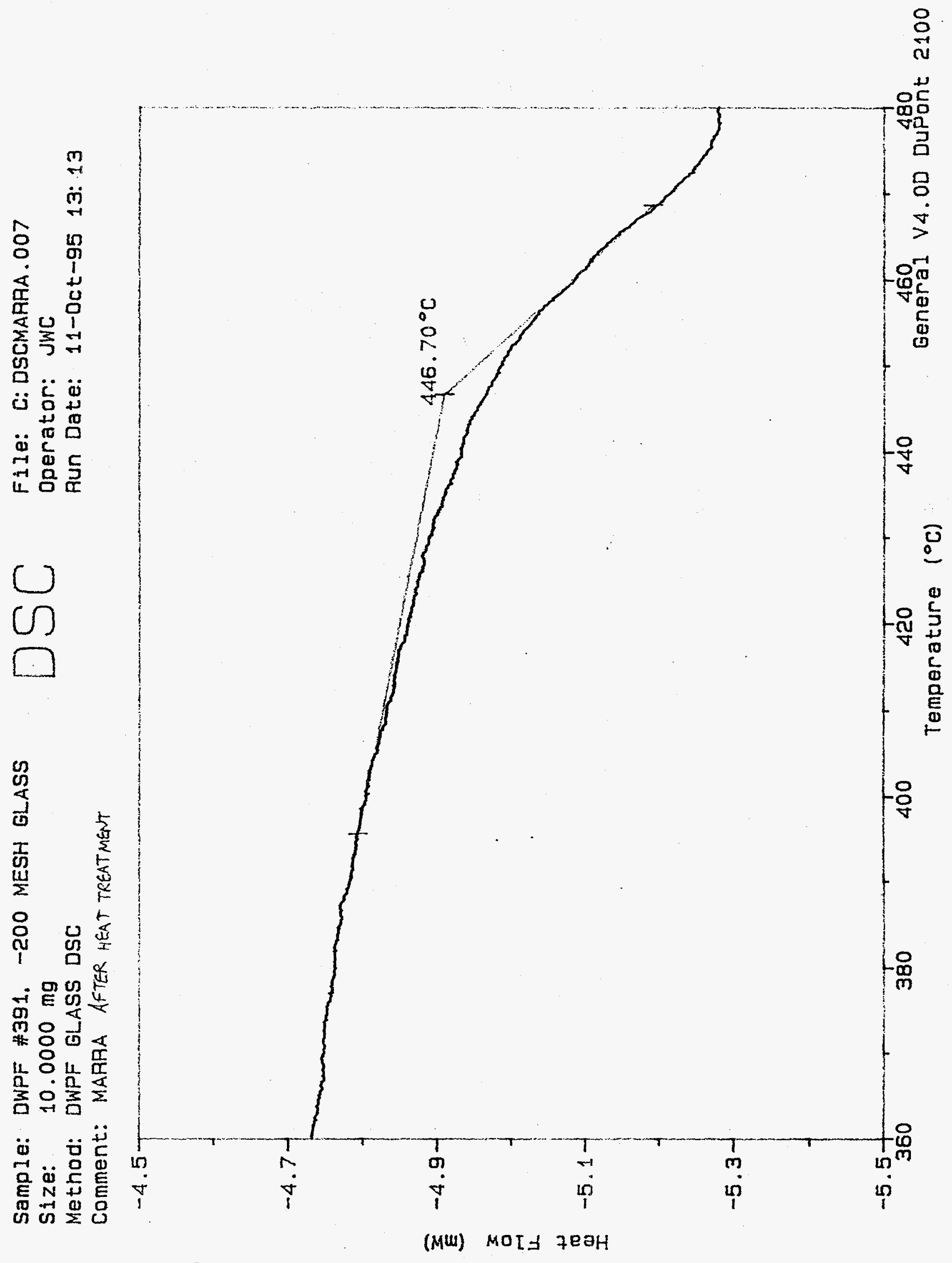


E. W. Holtzscheiter

WSRC-TR-95-0428

APPENDIX B: Thermogravimetric Analysis (TGA) Scans 


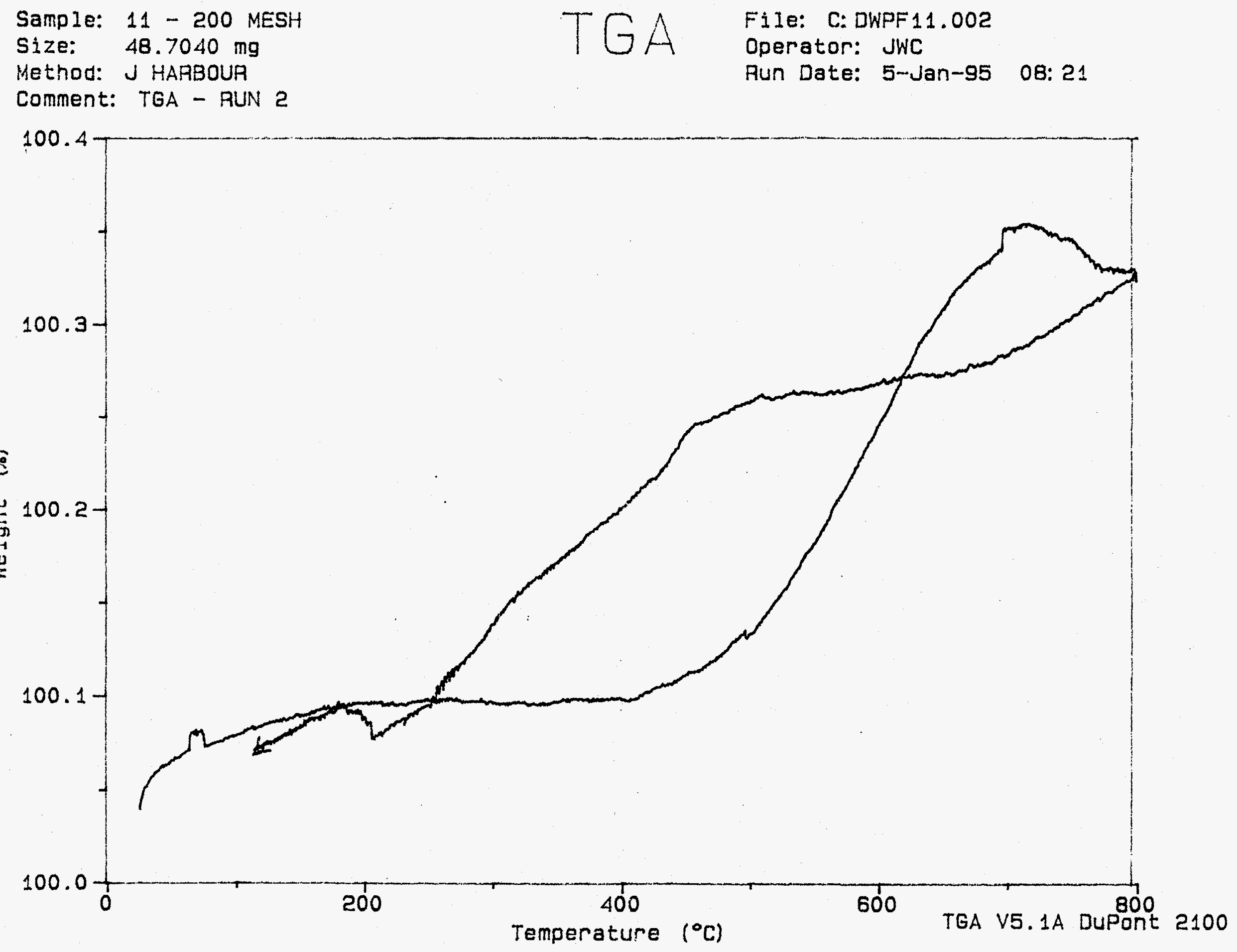




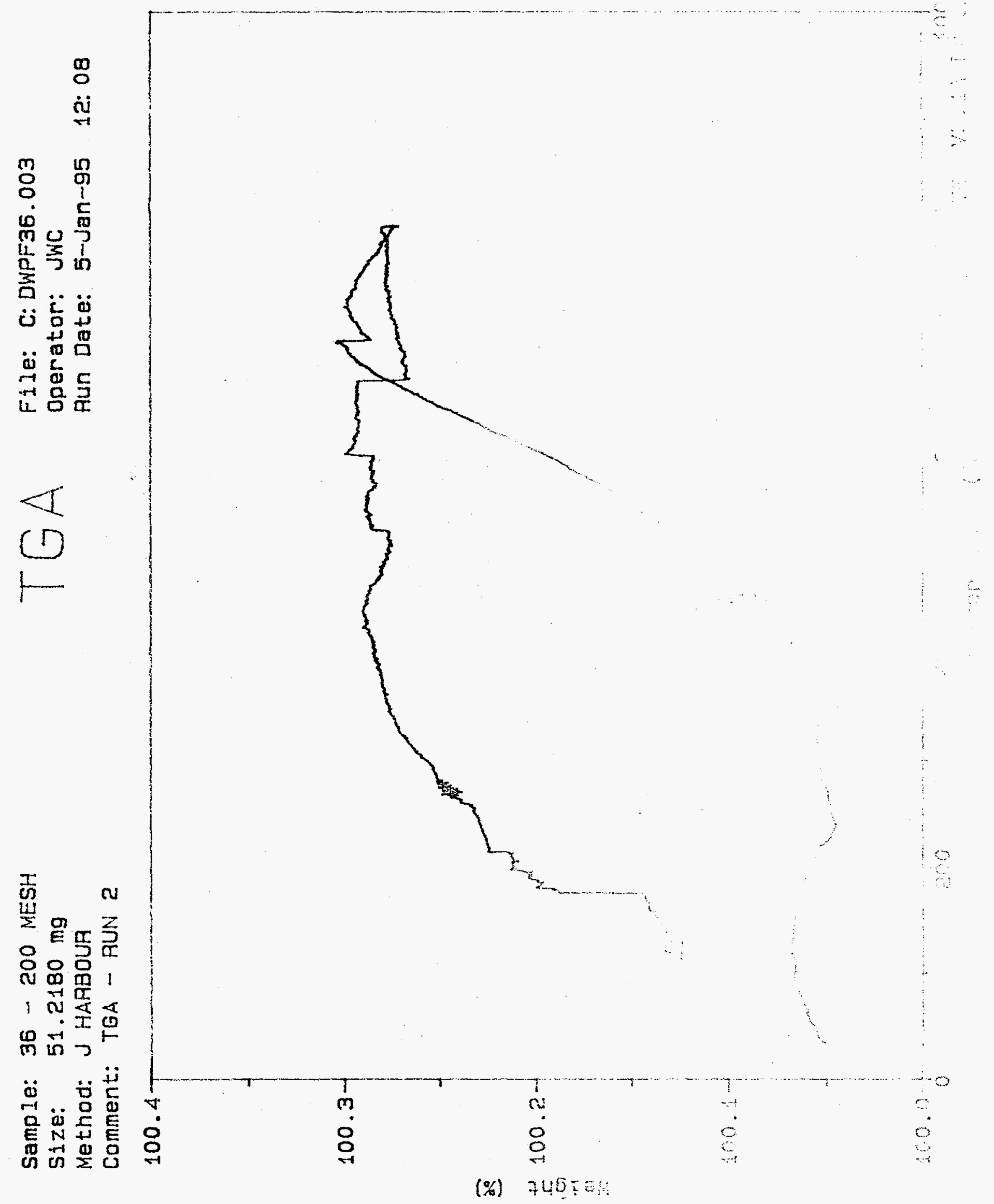




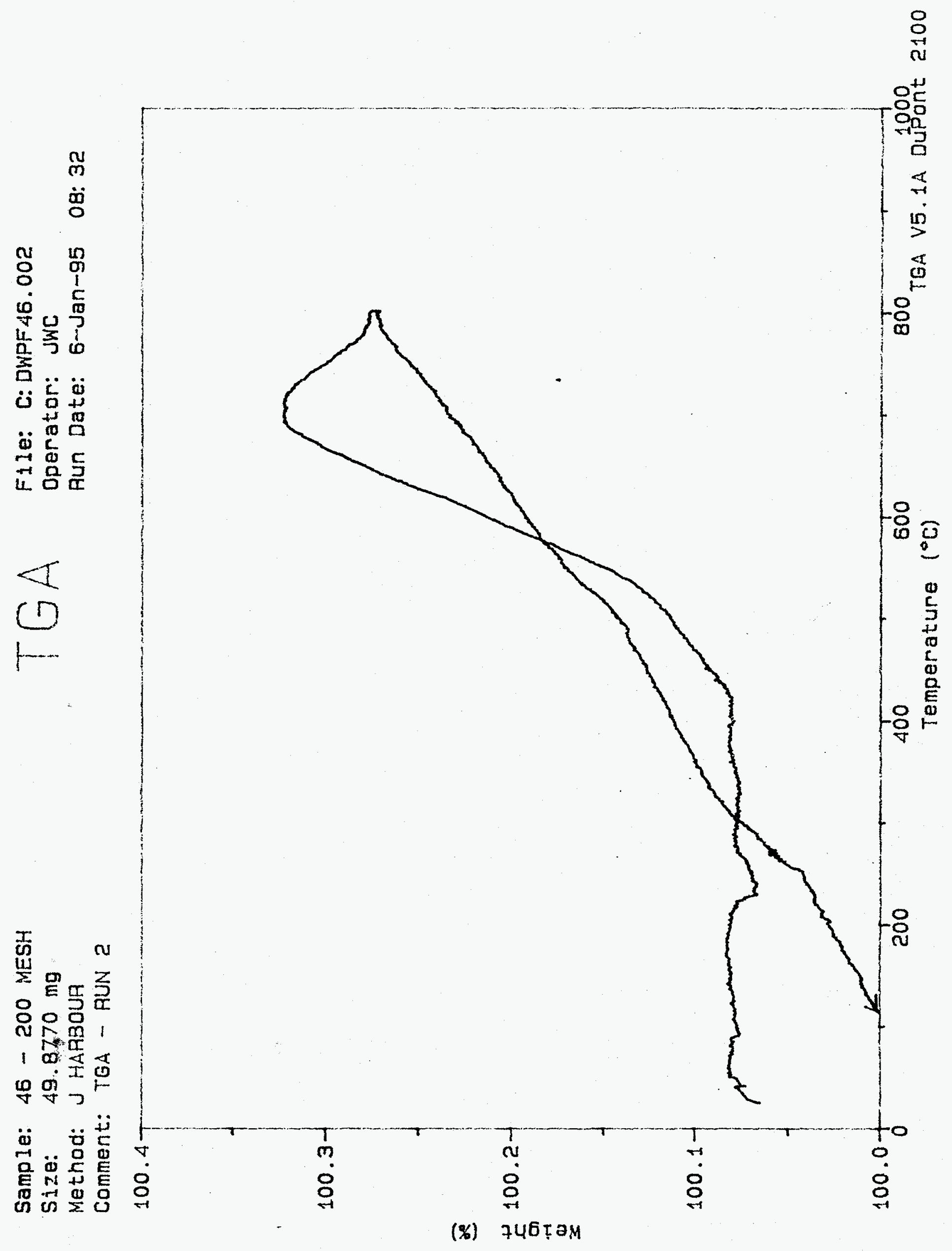




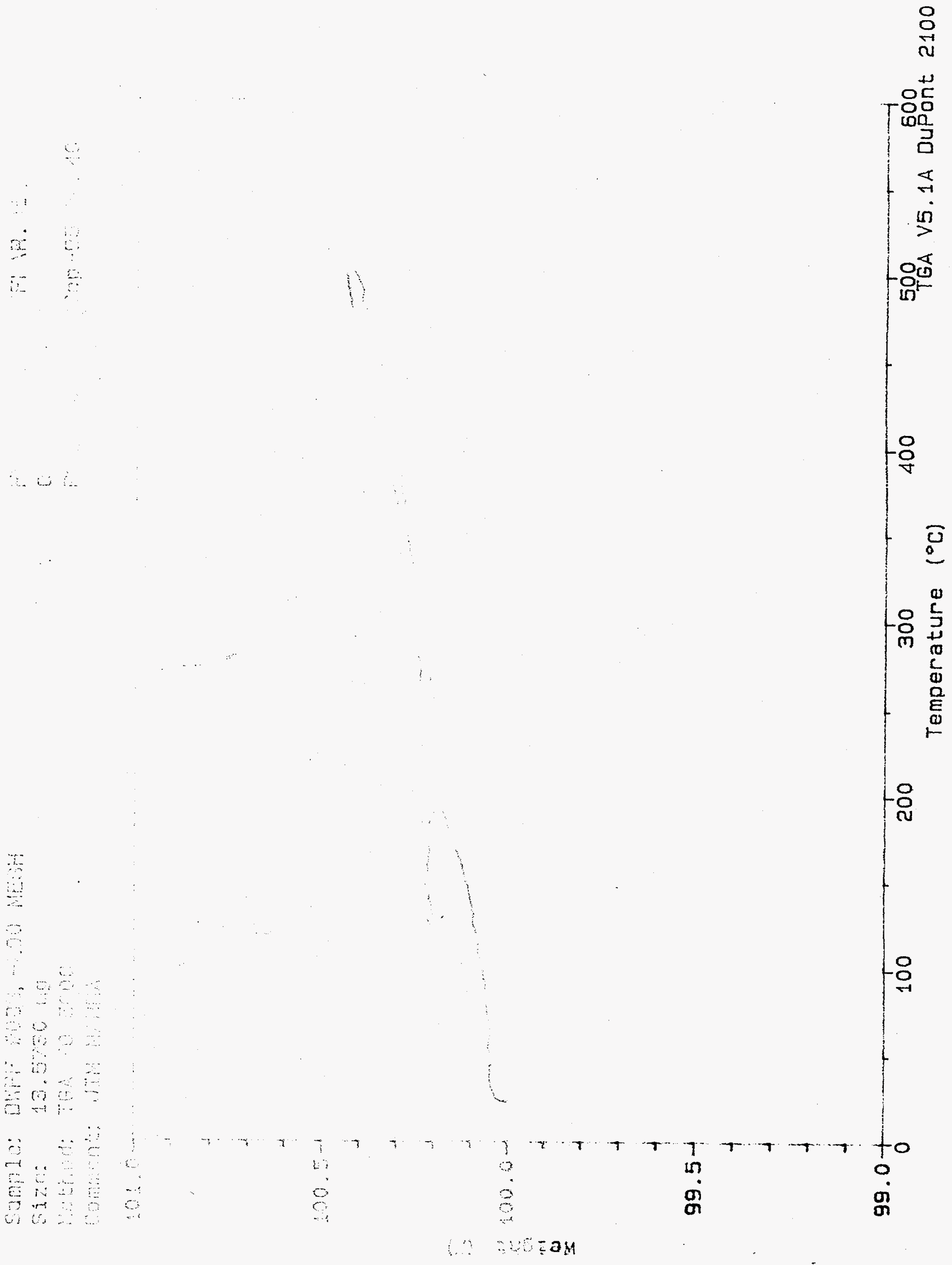




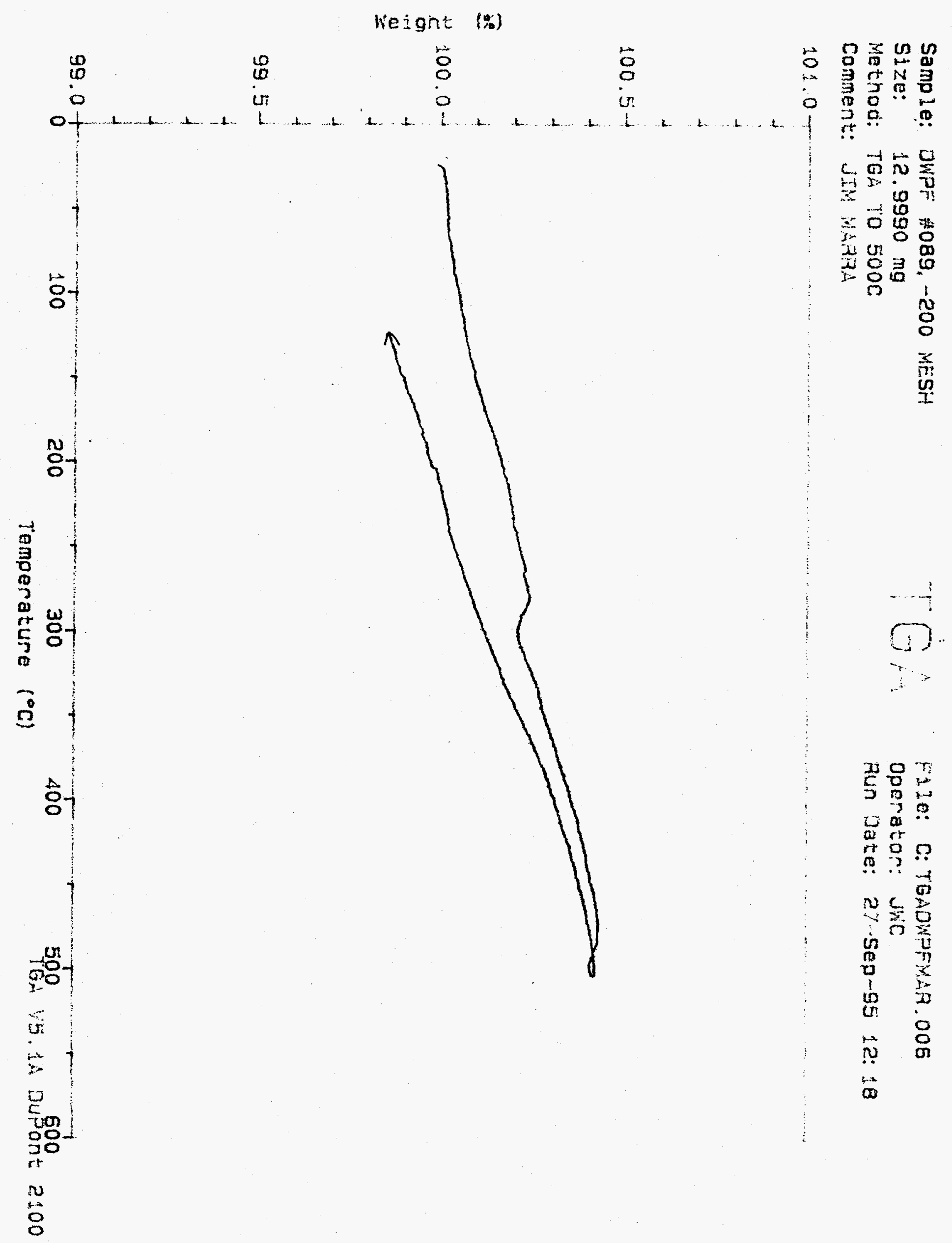




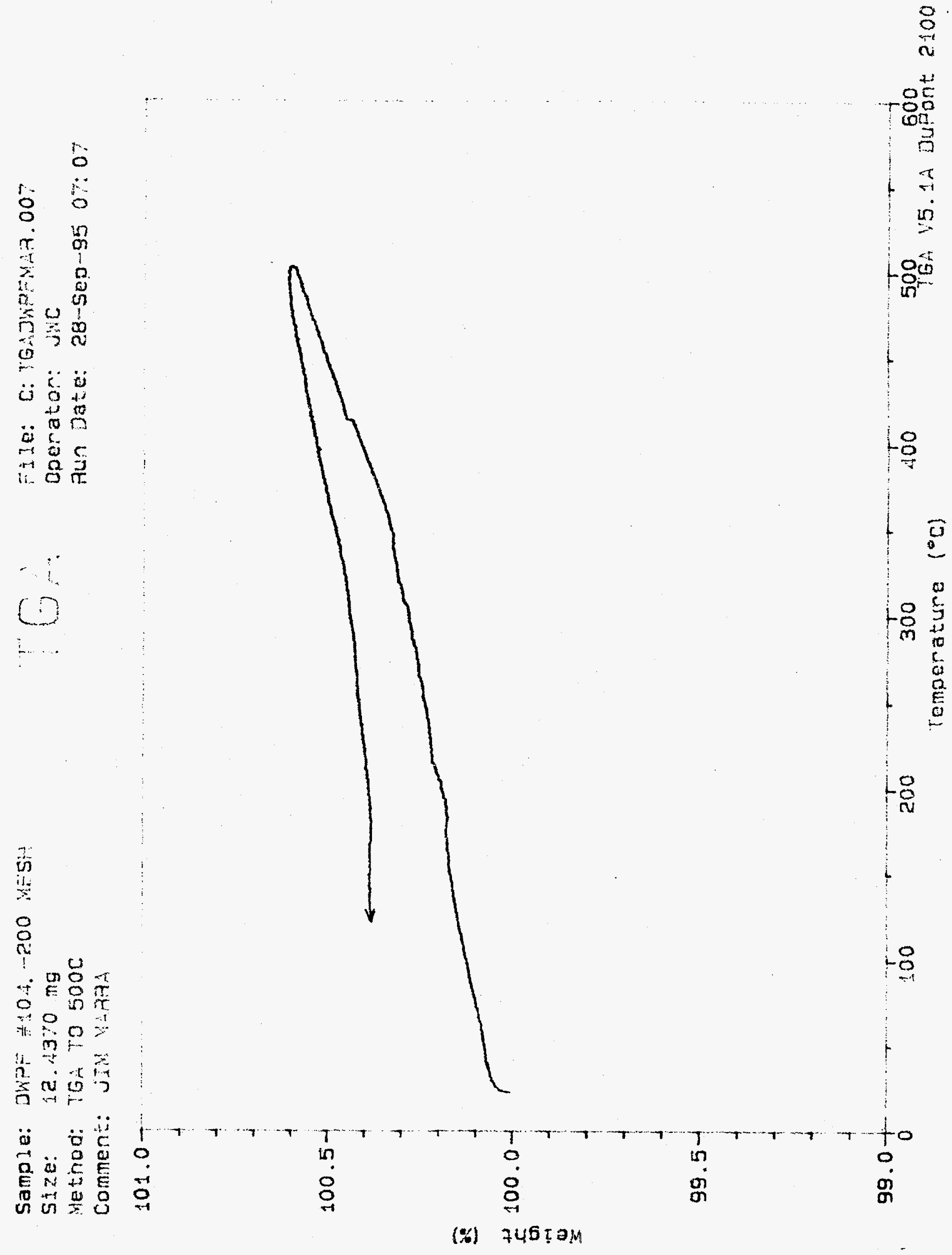


Sample: DWPF \#214, -200 MESH

Size: $\quad 17.8230 \mathrm{mg}$

TGA

File: C: TGADWPFMAR.012

Method: TGA TO $500 \mathrm{C}$ *

Operator: JWC

Comment: JIM MARAA

Run Date: 29-Sep-95 09: 09

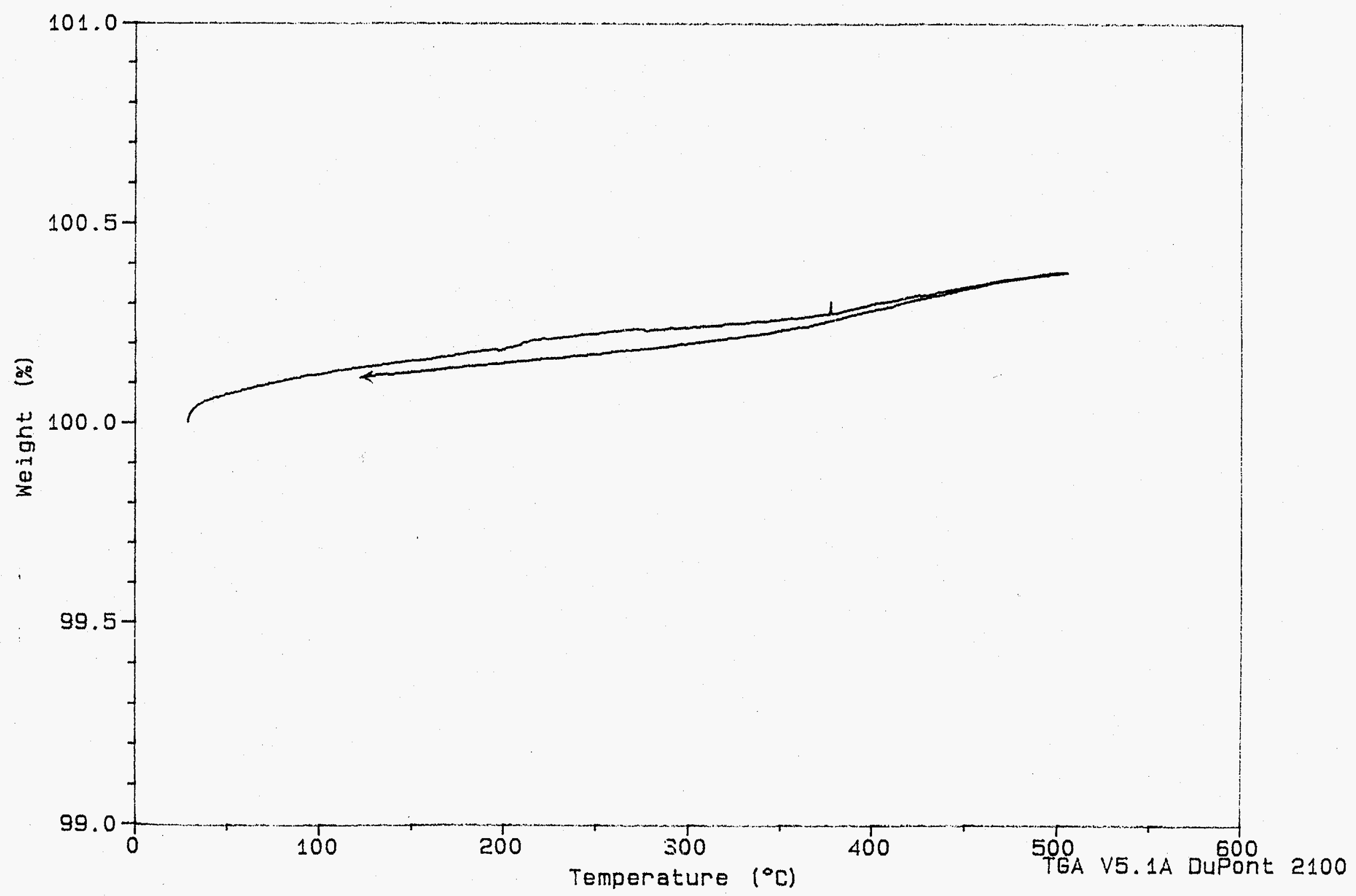


Sample: DWPF \#222, -200 MESH

Size: $\quad 15.5240 \mathrm{mg}$

Method: TGA TO 500C

Comment: JIM MARAA$$
101 .
$$

100.5

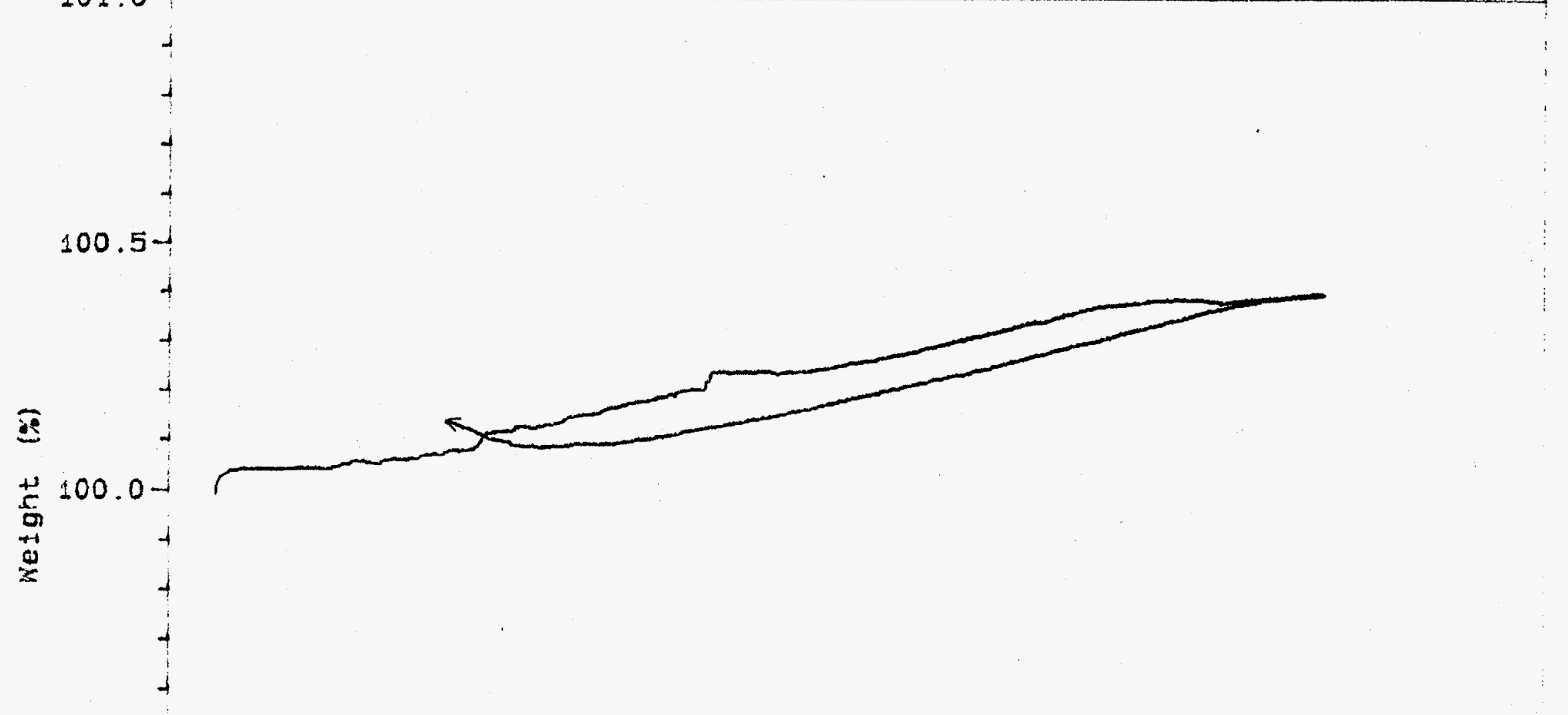

$99.5-$

$+$

$99.0+$
0

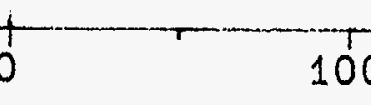

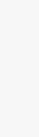

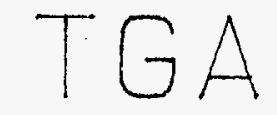

File: C: TGADWPFMAA.015

Operator: JWC

Run Date: 2-0ct-95 06: 58 


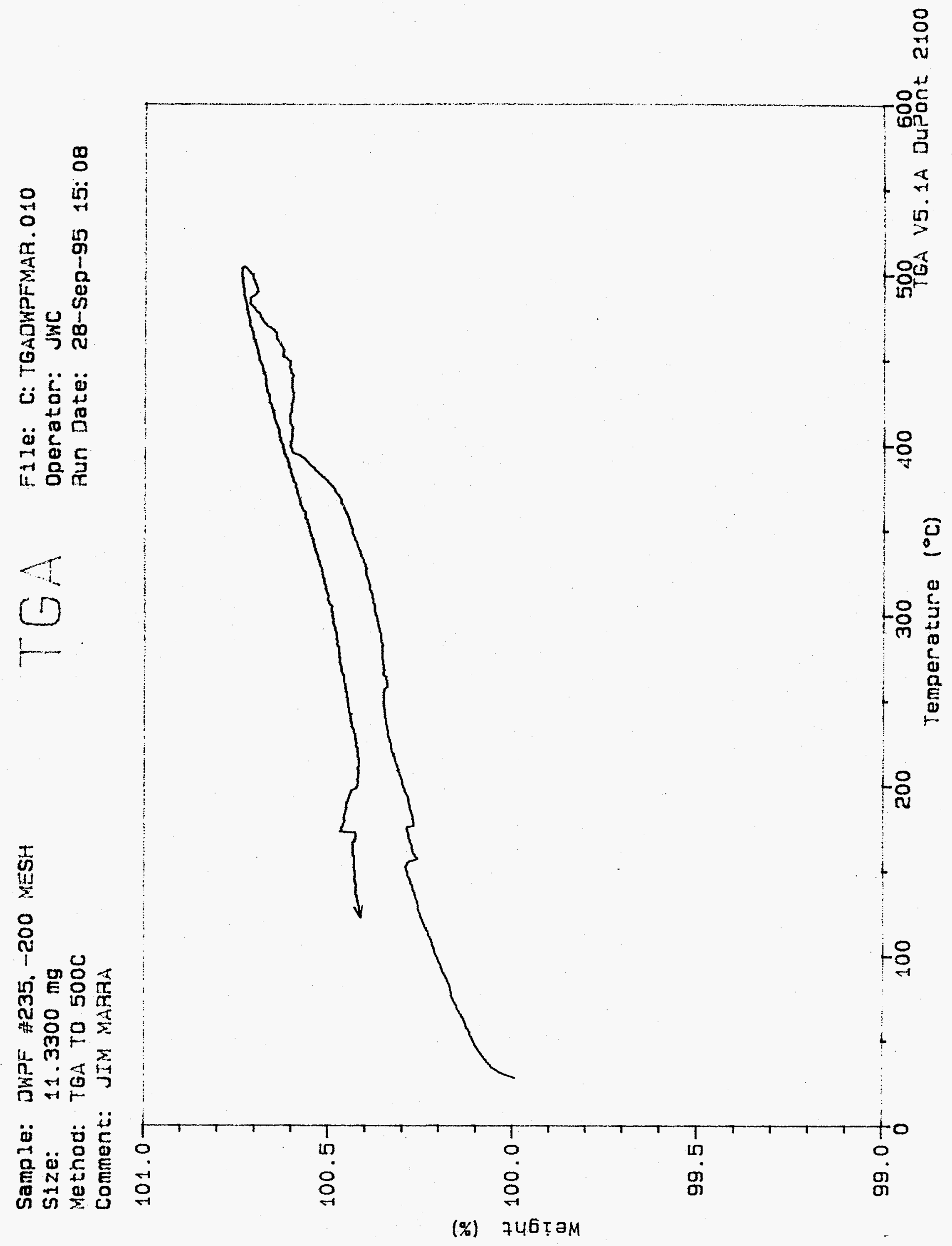




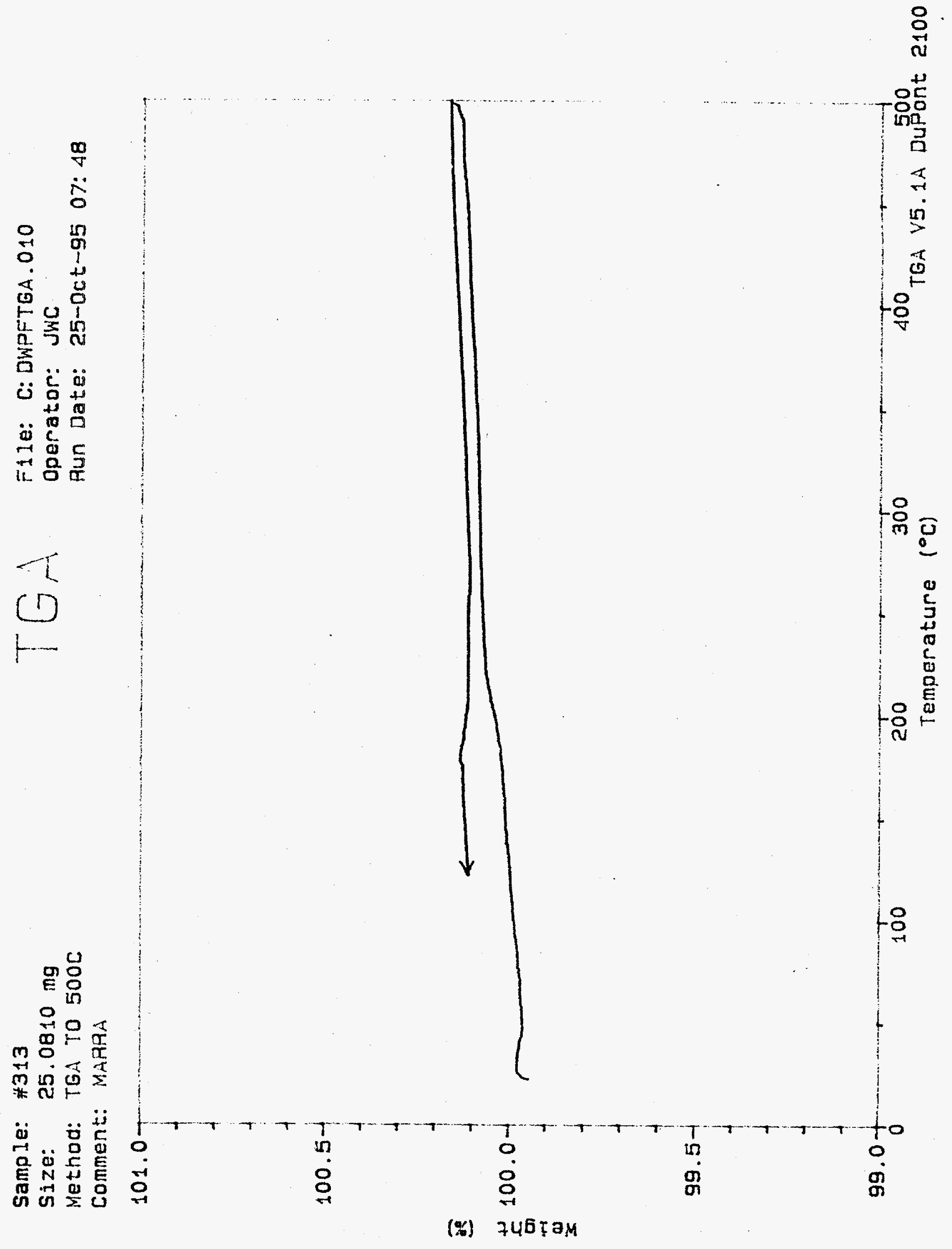




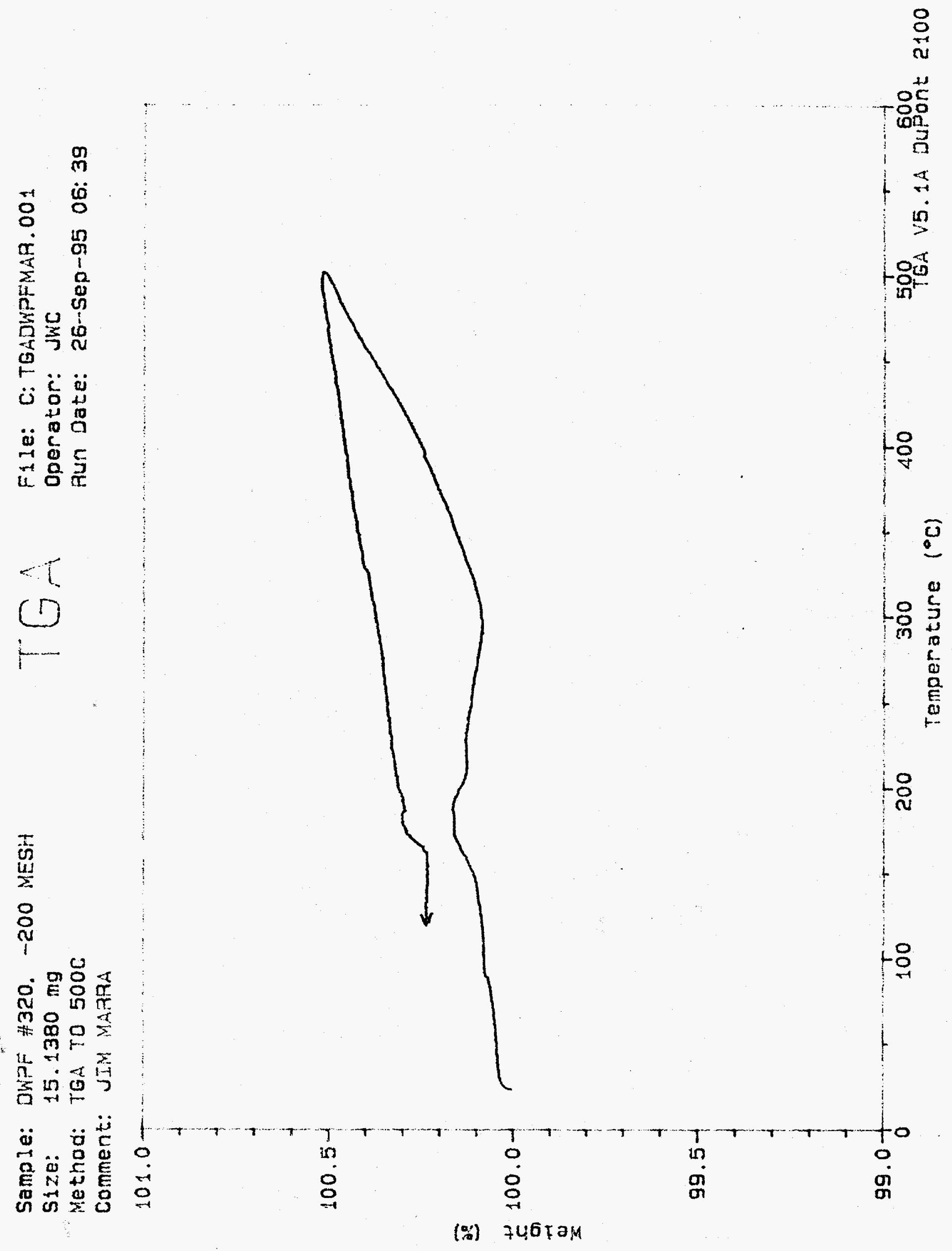




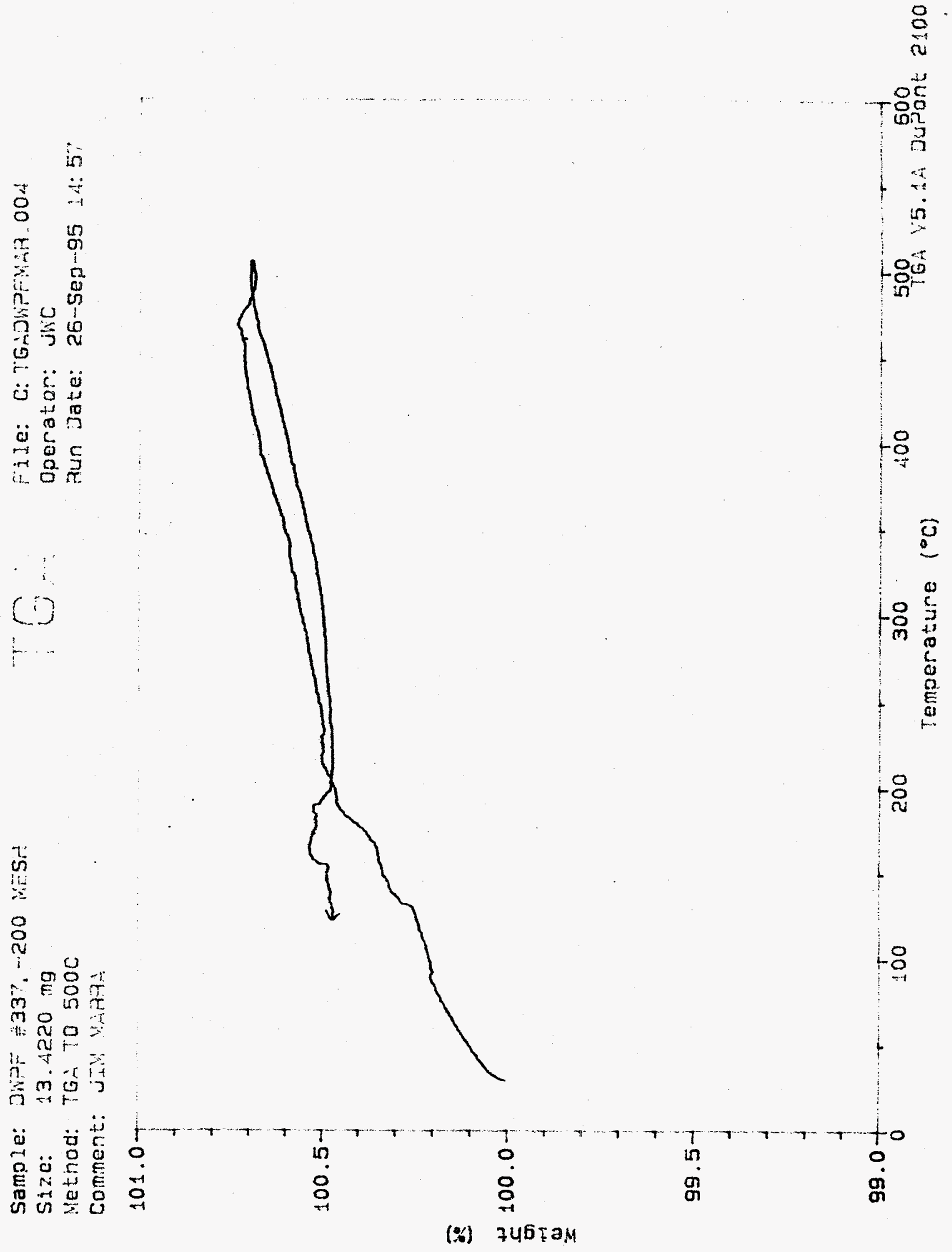




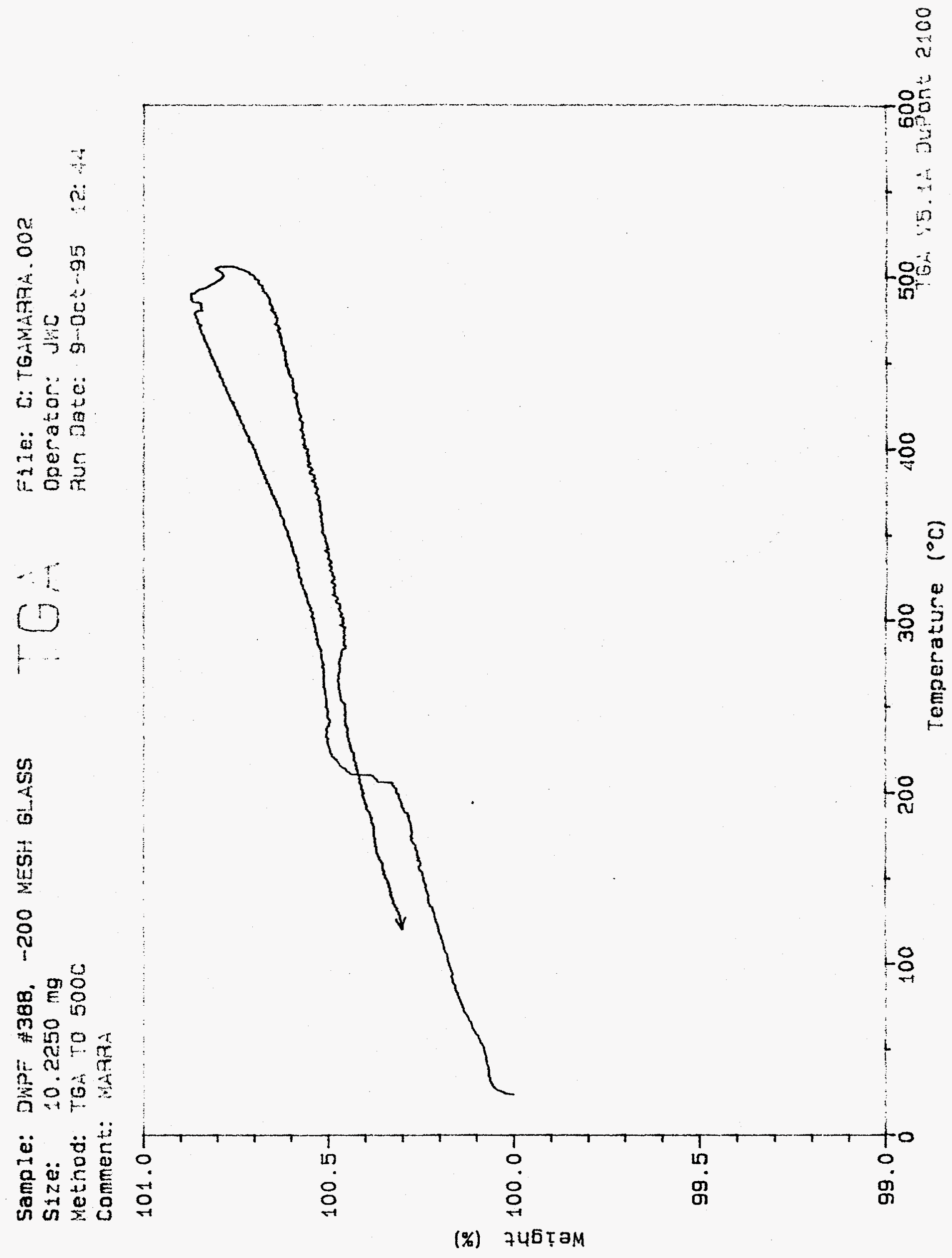


Sample: DWPF \#391. -200 MESH

Size: $25.0140 \mathrm{mg}$

TGA

File: C: TGAMARRA.00B

Method: TGA TO 450C

Operator: JWC

Comment: MARAA

Run Date: 17-0ct-95 16: 20

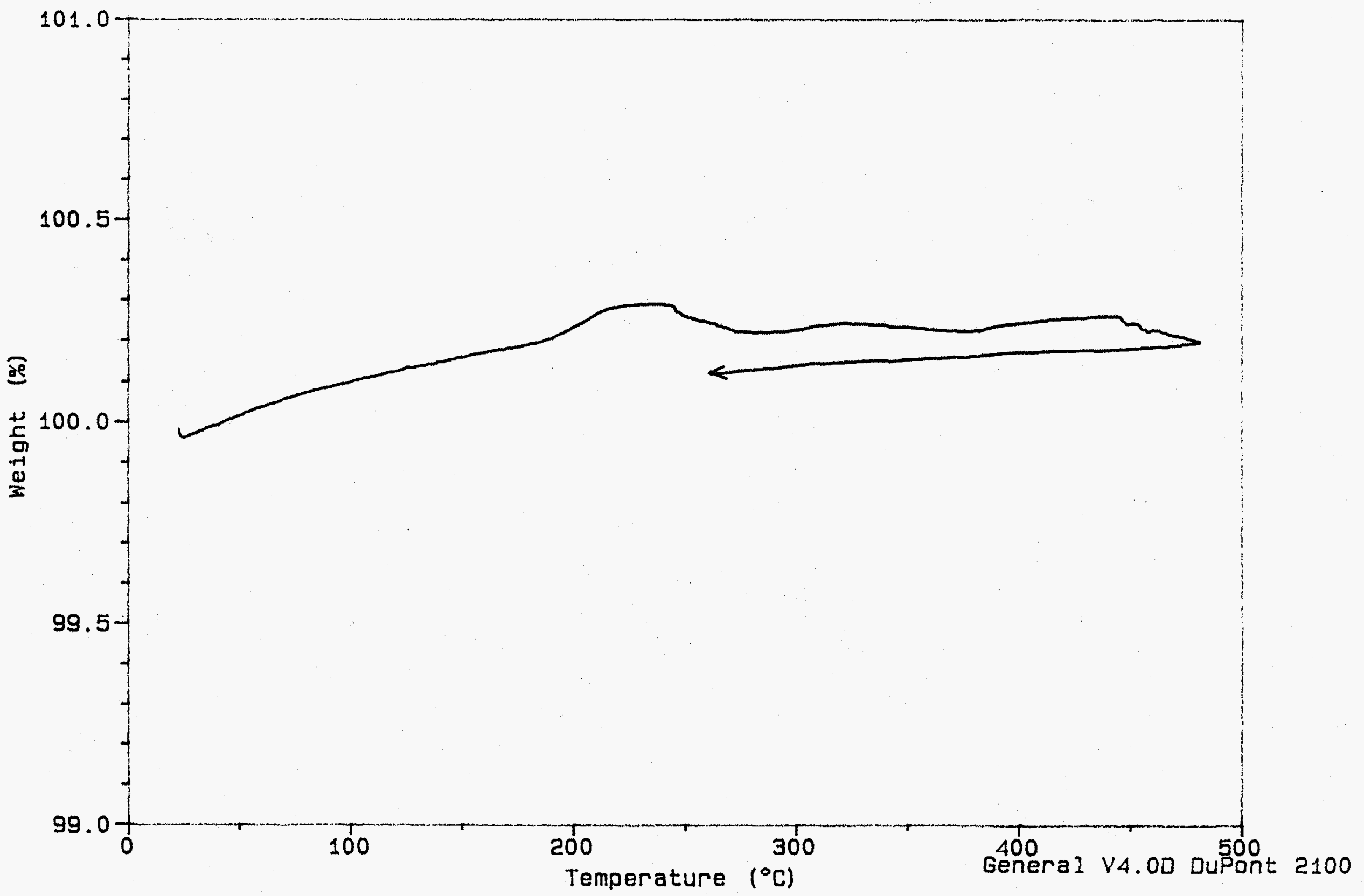


Sample: STANDARD - SGM 7-8

Size: $\quad 15.5970 \mathrm{mg}$

TGA

File: C: SGM78TGA.001

Method: I HARBOUR

Operator: JMM

Comment: TGA - RUN 1

Run Date: 3-Jan-95 10: 18

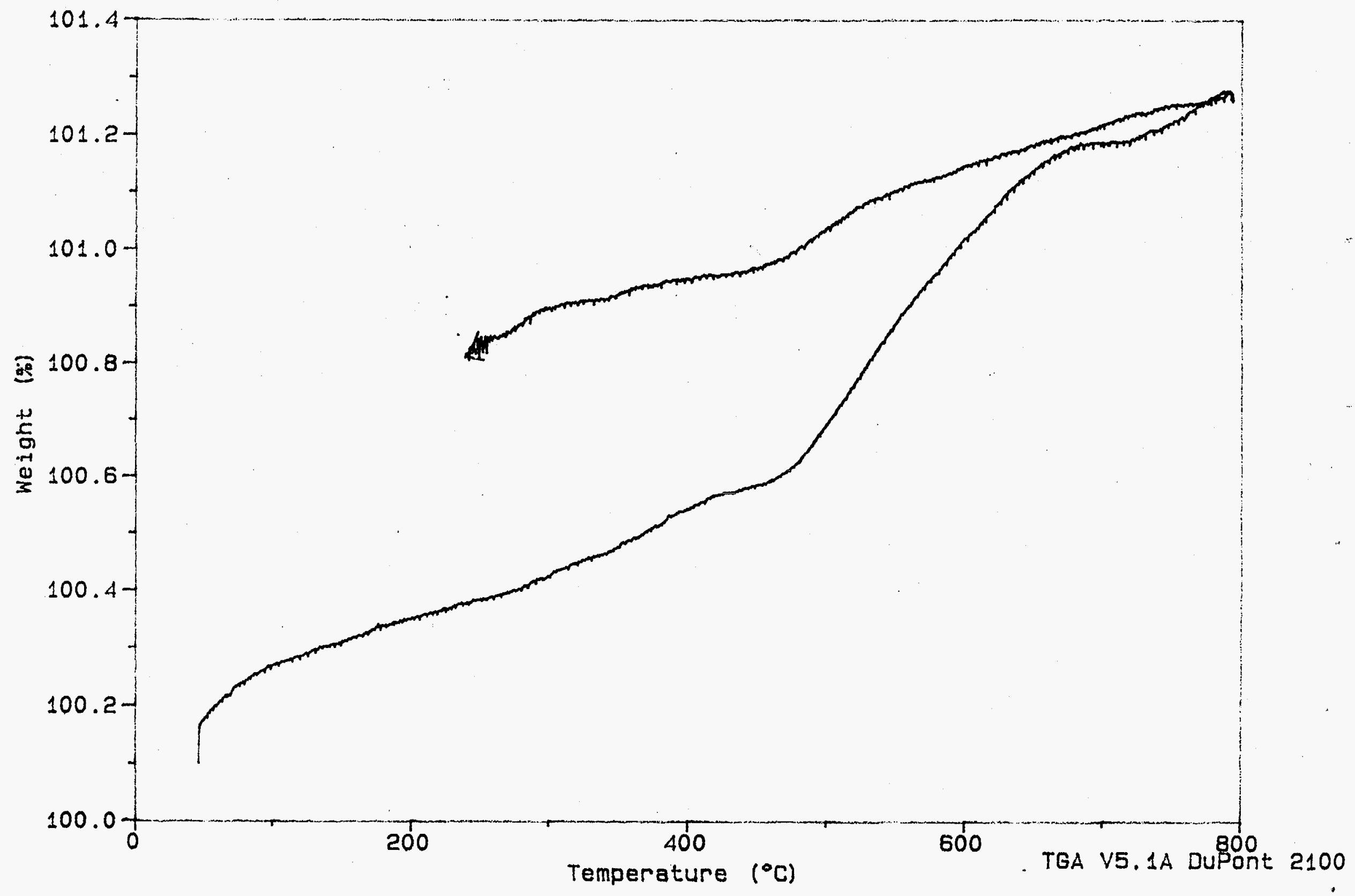

